\title{
Nitrate-Nitrogen Leaching from Onion Bed under Furrow and Drip Irrigation Systems
}

\author{
Parmodh Sharma, Manoj K. Shukla, Theodore W. Sammis, and Pradip Adhikari \\ Department of Plant and Environmental Sciences, New Mexico State University, MSC 3Q, P.O. Box 30003, Las Cruces, \\ NM 88003, USA \\ Correspondence should be addressed to Parmodh Sharma, sharmap@nmsu.edu
}

Received 4 December 2011; Accepted 24 February 2012

Academic Editor: María Cruz Díaz Álvarez

Copyright ( 2012 Parmodh Sharma et al. This is an open access article distributed under the Creative Commons Attribution License, which permits unrestricted use, distribution, and reproduction in any medium, provided the original work is properly cited.

\begin{abstract}
Water is a limited resource for crop production in arid areas of Southern New Mexico. The objectives of this study were to estimate the amount and depth of water and nitrate-nitrogen $\left(\mathrm{NO}_{3}-\mathrm{N}\right)$ fronts, water and $\mathrm{NO}_{3}-\mathrm{N}$ balances, and irrigation efficiencies for two onion (Allium cepa L.) fields under furrow and drip irrigation systems. Monthly soil samples were analyzed for $\mathrm{NO}_{3}-\mathrm{N}$ and chloride concentration for two onion growing seasons starting September 2006 to August 2009. The average amount of $\mathrm{NO}_{3}-\mathrm{N}$ in the soil water estimated by chloride tracer technique varied from 97.4 to $105.2 \mathrm{mg} \mathrm{L}^{-1}$ for furrow and 65.2 to $66.8 \mathrm{mg} \mathrm{L}^{-1}$ for drip-irrigated fields for the 60 - to $200-\mathrm{cm}$ depth. The $\mathrm{NO}_{3}-\mathrm{N}$ loadings below the rooting zone ranged from 145 to $150 \mathrm{~kg} \mathrm{ha}^{-1}$ for furrow- and 76 to $79 \mathrm{~kg} \mathrm{ha}^{-1}$ for drip-irrigated fields. The irrigation efficiencies varied from 78 to $80 \%$ for furrow- and $83 \%$ for drip- and N application efficiencies (NAEs) were 35 to $36 \%$ for furrow- and 38 to $39 \%$ for drip-irrigated fields. Small N fertilizer applications, delayed until onion bulbing starts, and water applications, preferably through drip irrigation, are recommended to reduce deep percolation and increase nitrogen and water efficiencies.
\end{abstract}

\section{Introduction}

Among all the elements needed for plant growth, nitrogen $(\mathrm{N})$ is considered the most important fertilizer element applied to soils because crop requirements for $\mathrm{N}$ are high compared with requirements for phosphorous $(\mathrm{P})$, potassium $(\mathrm{K})$, and other essential plant nutrients [1]. However, solubility of nitrate $\left(\mathrm{NO}_{3}\right)$ sources in water can cause rapid movement through soils, and among the various sources of $\mathrm{N}$ loss in agricultural fields, leaching is considered a major source of $\mathrm{NO}_{3}-\mathrm{N}$ loss under normal agricultural practices [1].

Crops differ in rooting depths, rooting densities, $\mathrm{N}$ and water requirements, and plant uptake efficiencies [2], and the percolation of $\mathrm{NO}_{3}-\mathrm{N}$ to deeper soil layers depends on the cropping systems. In addition to $\mathrm{N}$ fertilizers and water applied by irrigation or received through precipitation, type of irrigation system and soil physical properties also play important roles in $\mathrm{NO}_{3}-\mathrm{N}$ leaching to groundwater $[3,4]$. In arid regions like New Mexico, excess irrigation is also applied to flush salts out of the rooting zone to control soil salinization [5], leading to high $\mathrm{N}$ leaching. Nitrate loading to groundwater ranged from $165 \mathrm{~kg} \mathrm{ha}^{-1}$ $\mathrm{NO}_{3}-\mathrm{N}$ for irrigated sweet corn (Zea mays) to $366 \mathrm{~kg} \mathrm{ha}^{-1}$ $\mathrm{NO}_{3}-\mathrm{N}$ for irrigated potato (Solanum tuberosum) on sandy soils in Wisconsin [6]. In the Santa Maria, California, region, where crops such as potatoes, beans (Phaseolus), cauliflower (Brassica oleracea), celery (Apium graveolens), lettuce (Lactuca sativa), and broccoli (Brassica oleracea) are grown on different soils (loam, loamy sand, and sandy loam), mean $\mathrm{NO}_{3}-\mathrm{N}$ concentrations below the crop rooting zones ranged from 60 to $204 \mathrm{~kg} \mathrm{ha}^{-1}$ [7]. Similarly, for spring barley (Hordeum distichum L.) planted in sandy soils and fertilized with $100 \mathrm{~kg} \mathrm{~N} \mathrm{ha}^{-1}$, leaching losses of $65 \mathrm{~kg} \mathrm{~N} \mathrm{ha}^{-1}$ were reported [8]. Nitrate-N loading to groundwater was higher for onion than alfalfa (Medicago sativa L.) and chile (Capsicum annuum) under a furrow irrigation system of arid New Mexico [3].

The $\mathrm{N}$ use efficiency of onion has been reported to range from $15 \%$ [9] to 30\% [10] in furrow irrigation systems. Drip 
irrigation systems have been reported to reduce percolation of $\mathrm{NO}_{3}-\mathrm{N}$ below the vadose zone of bell pepper (Capsicum annuиm) [11]. Drip irrigation systems have the potential to supply water and $\mathrm{N}$ directly to onion roots and reduce water and $\mathrm{NO}_{3}-\mathrm{N}$ leaching to the deeper soil layers. Drip systems reported to apply $22 \%$ [12] to $30 \%$ [13] less water than furrow irrigation systems. Higher onion yields, larger bulb sizes, less $\mathrm{NO}_{3}-\mathrm{N}$ leaching, higher water use efficiency, and higher $\mathrm{N}$ fertilizer use efficiency were reported under drip irrigation systems compared to furrow irrigation systems [14].

The amount of $\mathrm{N}$ leaching can be estimated by measuring the concentration of chloride in irrigation water, and $\mathrm{N}$ and chloride concentrations in the soil below the rooting zone of a crop $[3,15,16]$. In these studies, soil $\mathrm{N}$ and chloride analyses were made after the harvest of crops to determine the growing season leaching fraction and amount of $\mathrm{N}$ reaching to the ground water. Most soils can supply $\mathrm{N}$ by mineralization, and $\mathrm{P}$ and $\mathrm{K}$ by weathering of minerals, but cannot supply a considerable amount of chloride. Also, chloride is involved in few biological reactions other than plant uptake and is present in most irrigation water [17]. Thus, chloride is uniquely suited as a tracer element to estimate $\mathrm{N}$ leaching below plant rooting zones, although the assumption that chloride is a conservative tracer and is not adsorbed or released by soil may not be always valid $[18,19]$. There may also be errors in the chloride balance unless all sources or sinks of chloride are determined [20]. Despite these limitations, the chloride tracer method has been used to determine $\mathrm{NO}_{3}-\mathrm{N}$ loading to the groundwater because the method is fast and easy to use and is less expensive method than constructing a lysimeter. However, there is a need to expand this technique by including soil nitrate$\mathrm{N}$, chloride, and irrigation measurements throughout the growing season. Therefore, objectives of this study were to determine how the existing management practices of onion in New Mexico can be improved to reduce $\mathrm{NO}_{3}-\mathrm{N}$ leaching and improve water application and $\mathrm{N}$ efficiencies. The hypothesis of the study was that the transport behavior of chloride in soils is similar to that of $\mathrm{NO}_{3}-\mathrm{N}$, and that chloride can be used as a tracer to determine the amount of $\mathrm{NO}_{3}$-N reaching to the groundwater throughout the growing season of onion in New Mexico.

\section{Materials and Methods}

2.1. Site Description. This study was conducted during two onion growing seasons from 2006 to 2009 in two fields under two irrigation systems. In furrow-irrigated field, onion was planted on 2 November 2006 and harvested on 14 July 2007; this period was considered as growing season 1 whereas onion planted on 25 September 2008 and harvested on 18 June 2009 was considered as growing season 2. Similarly, onion planted on 27 September 2006 and harvested on 8 June 2007 was considered as growing season 1 and onion planted on 23 February 2008 and harvested on 10 August 2008 was considered as growing season 2 in drip-irrigated field. For the previous eight years, both fields were planted with sudan grass (Sorghum sudanense) after the onion harvest of growing season 1 until onion planted for growing season 2. No $\mathrm{N}$ fertilizer was applied to the sudan grass and it was harvested three times during the growing season in the furrow-irrigated field, and one time in the drip-irrigated field where the biomass was left on the soil surface at the end of each cut and incorporated into the soil at the end of the growing season. The furrow-irrigated onion field was located on the Leyendecker Plant Science Research Centre (PSRC) at $32^{\circ} 11^{\prime} \mathrm{N}$ and $106^{\circ} 44^{\prime} \mathrm{W}$ and the drip-irrigated onion field was located on the Fabian Garcia Research Center (FGRC) at $32^{\circ} 16^{\prime} \mathrm{N}$ and $106^{\circ} 46^{\prime} \mathrm{W}$ of New Mexico State University (NMSU) near Las Cruces, New Mexico. Soils at both sites were classified as Glendale (fine-silty, mixed, calcareous, thermic typic Torrifluvents)-Harkey (coarse-silty, mixed, calcareous, thermic typic Torrifluvents) series [21]. The average annual precipitation for the experimental sites is $25.3 \mathrm{~cm}$, and the average annual temperature is $17.7^{\circ} \mathrm{C}$. The groundwater table was below $2 \mathrm{~m}$ in depth at both experimental sites, and both fields were irrigated with groundwater [22].

2.2. Seedbed Preparation. The fields at PSRC and FGRC were prepared under conventional tillage that included disking, chiseling, plowing, leveling, listing, and bed shaping. Disking was done to alleviate surface soil compaction and to incorporate sudan grass stubble into the soil in both the fields. Triple superphosphate was broadcasted at a rate of $200 \mathrm{~kg} \mathrm{P}_{2} \mathrm{O}_{5} \mathrm{ha}^{-1}$ on both onion fields before moldboard plowing. Both fields were laser leveled, bed shaped with $56 \mathrm{~cm}$ beds and $46 \mathrm{~cm}$ furrows, and two rows of onions transplanted into each bed $28 \mathrm{~cm}$ apart on 2 November 2006 and 25 September 2008 in the field located at PSRC and on 27 September 2006 and 23 February 2008 in the field located at FGRC. The length of row was $210 \mathrm{~m}$ at PSRC and $132 \mathrm{~m}$ at FGRC. The field at the PSRC was furrow irrigated while the field at the FGRC was drip-irrigated using T-tape (TTape: TSX-508-08-670, T-Systems, San Diego, CA) with an emitter spacing of $20 \mathrm{~cm}$ and a flow rate of $0.22 \mathrm{~cm} \mathrm{~h}^{-1}$ laid in the center of each bed between the two onion rows at a $10 \mathrm{~cm}$ depth. Onions were irrigated 19 times with total gross water application of $95 \mathrm{~cm}$, and 21 times with total gross water application of $100 \mathrm{~cm}$ during growing seasons 1 and 2, respectively, in the furrow-irrigated field. Onion in drip-irrigated field received a total gross water application of $81 \mathrm{~cm}$ using 42 irrigation applications in growing season 1 and $72 \mathrm{~cm}$ using 40 irrigation applications in growing season 2. The amount of water applied during each irrigation event was measured with a flow meter (McCrometer, Inc., Hemet, $\mathrm{CA}$ ) in each field. The precipitation data was obtained from weather stations located at each experimental site. The water application efficiency was calculated as the ratio of total water stored in the onion rooting zone during irrigation $\left(E_{t}+\Delta\right.$ storage) and total water applied [23].

Urea ammonium nitrate (URAN) liquid fertilizer was the source of $\mathrm{N}$ applied in both the fields. Urea ammonium nitrate was applied at a rate of $49.2 \mathrm{~kg} \mathrm{Nha}^{-1}$ per irrigation in the furrow-irrigated field. During growing season 1 , six 
irrigations with URAN fertilizer were applied during 2007 in the months of February, March, and April (total of $295 \mathrm{~kg} \mathrm{Nha}^{-1}$ ) and same number of fertilizer applications (total of $295 \mathrm{~kg} \mathrm{Nha}^{-1}$ ) were also made during growing season 2 in the furrow-irrigated field. In the drip-irrigated field, URAN was applied at an average rate of $36.5 \mathrm{~kg} \mathrm{~N} \mathrm{ha}^{-1}$ through eight irrigations (total of $292 \mathrm{~kg} \mathrm{Nha}^{-1}$ ) during growing season 1 and $35.8 \mathrm{~kg} \mathrm{Nha}^{-1}$ per irrigation through eight irrigations (total of $286 \mathrm{~kg} \mathrm{Nha}^{-1}$ ) during growing season 2 through the drip tape via injectors (H. E. Anderson company, Muskogee, OK). Nitrogen application efficiency was calculated as the ratio of total $\mathrm{N}$ uptake and total $\mathrm{N}$ applied. Nitrogen use efficiency was calculated as the ratio of total $\mathrm{N}$ uptake and total available $\mathrm{N}$ (initial soil $\mathrm{N}$ at a 0 $50 \mathrm{~cm}$ depth $+\mathrm{N}$ fertilizer applied) [14].

2.3. Soil Sampling and Analysis. Twenty-four soil core samples were collected from three locations and four depths (0$10,10-30,30-40$, and $40-60 \mathrm{~cm}$ ) from both fields (2 fields $\times 3$ locations $\times 4$ depths $=24)$. Cores were trimmed in the laboratory, and soil bulk density (BD) was determined by the core method [24]. After determining soil BD, all soil cores were immediately placed in a water tray for 1 to $2 \mathrm{~d}$ at room temperature $\left(24^{\circ} \mathrm{C}\right)$ to fully saturate by capillary rise, and saturated hydraulic conductivity $\left(K_{s}\right)$ was determined by the constant head method [25].

Bulk soil samples were collected from each field at the end of each month from six depths $(0-10,10-30,30-40,40$ $60,60-85$, and $85-110 \mathrm{~cm}$ ) and three locations (2 fields $\times$ 3 locations $\times 6$ depths $=36$ soil samples) from September 2006 to August 2009. Gravimetric soil moisture content for each bulk soil sample was determined immediately after sampling [26]. The gravimetric water content was multiplied by $\mathrm{BD}$ to calculate the volumetric soil water content $(\theta)$. The rest of each soil sample was stored in a cold room at $4^{\circ} \mathrm{C}$ until further analysis. Irrigation water samples collected during each month from both fields were analyzed for electrical conductivity (EC), $\mathrm{pH}$, nitrate, and chloride from both fields. Soil samples were also collected from 150- and $200-\mathrm{cm}$ depths during the last week of March and at the time of harvest from both fields to examine change in the concentration of $\mathrm{NO}_{3}-\mathrm{N}$ and chloride.

Bulk soil samples were air dried for 48 hours, ground, and passed through a 2-mm diameter sieve. Fifty-one grams of sieved soil $(<2 \mathrm{~mm}$ diameter $)$ was used for particle size analysis by the hydrometer method [27]. Nitrate-N was determined by an automated spectrophotometric method using a Technicon autoanalyzer from soil- $\mathrm{KCl}$ extracts. The extracts were prepared by adding $25 \mathrm{~mL}$ of $2.0 \mathrm{M} \mathrm{KCl}$ to $2.5 \mathrm{~g}$ of soil, shaking the suspension for 1 hour, and filtering through filter paper (Whatman number 2) [28]. Chloride was determined with a 798 MPT Titrino titrator using silver nitrate solution $(0.1 \mathrm{M})$. Electrical conductivity (EC) and $\mathrm{pH}$ were measured for a solution of $(1: 2$ soil: water $)$ using an EC electrode and $72 \mathrm{pH}$ meter, respectively. Soil samples from six depths in both fields were also analyzed for organic matter $(\mathrm{OM})$, exchangeable sodium percentage (ESP), sodium adsorption ratio (SAR), phosphorous (P), and potassium (K) at the New Mexico State University Soil and Water Testing (SWAT) Laboratory.

2.4. Onion Rooting Depth and Biomass. Onion rooting depth was determined by excavating two pits at each field just before each harvest. Two plants from each pit were excavated along with their roots at a depth increment of $20 \mathrm{~cm}$ from the top of the bed to a depth of $50 \mathrm{~cm}$. The soil was gently washed in the lab and roots were separated, air dried, and weighed.

Onion samples were collected at monthly intervals from February until harvest during growing season 2 in furrowand drip-irrigated fields for $\mathrm{N}$ uptake determination. For aboveground biomass determination, the crop was manually harvested before each harvest from four randomly selected plots $(2.4 \mathrm{~m} \times 1 \mathrm{~m})$ at each field. Wet and dry plant biomass and onion yields were determined, separately, for each plot on a per-hectare basis. The plant samples were weighed fresh, then dried at $68^{\circ} \mathrm{C}$ for $72 \mathrm{~h}$ and reweighed to determine plant moisture content. The air-dried onion bulbs were analyzed for $\mathrm{NO}_{3}-\mathrm{N}$, total $\mathrm{N}$ and chloride at the SWAT lab of NMSU.

2.5. Crop Coefficient. The reference evapotranspiration $\left(E_{t_{0}}\right)$ for grass using Penman's equation was obtained from NMSU weather station located at each experimental field. The crop coefficient $\left(K_{c}\right)$ was calculated as follows:

$$
K_{c}=B_{0}+B_{1} \sum_{i=1}^{n} \mathrm{GDD}+B_{2}\left(\sum_{i=1}^{n} \mathrm{GDD}\right)^{2}+B_{3}\left(\sum_{i=1}^{n} \mathrm{GDD}\right)^{3},
$$

where $i=$ day and $n=$ total number of days, $B_{0}$ is the intercept, and $B_{1}, B_{2}$, and $B_{3}$ are regression coefficients for onion [29]. Growing-degree-days (GDD) were calculated as

$$
\mathrm{GDD}=\frac{\left(T_{\max }+T_{\min }\right)}{2}-T_{b}
$$

where $T_{\max }=$ daily maximum temperature $\left({ }^{\circ} \mathrm{C}\right) ; T_{\min }=$ daily minimum temperature $\left({ }^{\circ} \mathrm{C}\right) ; T_{b}=$ base temperature $\left({ }^{\circ} \mathrm{C}\right)$. The base temperature was set at $4^{\circ} \mathrm{C}[30] . K_{c}$ is defined as the ratio of crop evapotranspiration $\left(E_{t}\right)$ and $E_{t_{o}}$; therefore, $K_{c}$ was multiplied by $E_{t_{o}}$ to calculate $E_{t}$.

2.6. Soil Water Content. Diurnal variations of $\theta$ in the onion beds were monitored by time domain reflectometry (TDR) sensors (Campbell Scientific, Inc., Logan, Utah). Each TDR system included one CR 10X datalogger, one SDMX50 multiplexer, one TDR 100, and eight CS-640 probes powered by a $12 \mathrm{~V}$ deep-cycle battery at each experimental site. A set of two probes was installed at depths of 20 and $50 \mathrm{~cm}$ from the top of the onion bed at four locations in each experimental field. Total of sixteen TDR sensors were installed and programmed to provide half hourly readings for the entire growing seasons at both experimental sites.

2.7. Chloride Tracer Technique. Chloride is present in almost every source of irrigation water and is either taken up by plants or remains in the water. Chloride is assumed 
to be a conservative ion in this approach. As most soils do not adsorb or release chloride, the irrigation leaching fraction (LF) can be calculated by taking the ratio of chloride concentration in irrigation water to chloride concentration in the drainage water [15]. The LF is defined as the fraction of water moving below the rooting zone portion of the soil profile and is expressed as

$$
\mathrm{LF}=\frac{\left(E_{t} \mathrm{Cl}_{i}\right)-\mathrm{Cl}_{c}}{\left(E_{t} \mathrm{Cl}_{p}\right)-\mathrm{Cl}_{c}},
$$

where $E_{t}$ is the seasonal $E_{t}\left(\mathrm{~kg} \mathrm{H}_{2} \mathrm{O} \mathrm{ha}^{-1}\right), \mathrm{Cl}_{i}$ is the chloride concentration $\left(\mathrm{kg} \mathrm{Cl}^{-1}\right.$ per $\left.\mathrm{kg} \mathrm{H}_{2} \mathrm{O}\right)$ in the irrigation water, $\mathrm{Cl}_{p}$ is the chloride concentration $\left(\mathrm{kg} \mathrm{Cl}^{-1}\right.$ per $\left.\mathrm{kg} \mathrm{H}_{2} \mathrm{O}\right)$ in the soil water below the rooting zone, and $\mathrm{Cl}_{c}$ is the amount of chloride taken up by the crop $\left(\mathrm{kg} \mathrm{Cl}^{-1} \mathrm{ha}^{-1}\right)$ [16]. Irrigation efficiency (IE) was calculated by subtracting the LF from 1. The amount of $\mathrm{N}\left(\mathrm{kg} \mathrm{ha}^{-1}\right)$ leaching in the groundwater $\left(\mathrm{N}_{p}\right)$ was calculated as

$$
\mathrm{N}_{p}=\mathrm{Cl}_{a} \frac{\left(\mathrm{NO}_{3}^{-}-\mathrm{N}\right)_{s}}{\mathrm{Cl}_{s}},
$$

where $\mathrm{Cl}_{a}$ is the amount of chloride $\left(\mathrm{kg} \mathrm{ha}^{-1}\right)$ in the irrigation water and was calculated based on the concentration of chloride in the irrigation water, the volume of irrigation water, and the amount of water taken up by the crop, $\left(\mathrm{NO}_{3}-\right.$ $\mathrm{N})_{s}$ is the concentration of $\mathrm{NO}_{3}-\mathrm{N}$ in the soil $\left(\mathrm{mg}\left(\mathrm{NO}_{3}-\mathrm{N}\right)\right.$ $\mathrm{mg}^{-1}$ soil), and $\mathrm{Cl}_{s}$ is the chloride ion concentration in the soil ( $\mathrm{mg} \mathrm{Cl}^{-1} \mathrm{mg}^{-1}$ soil).

2.8. Water Balance. The following equation was used to estimate the water balance in both fields:

$$
\Delta S=P+I-E_{t}-\mathrm{DP}
$$

where $\Delta S$ is change in soil water storage $(\mathrm{cm}), P$ is precipitation $(\mathrm{cm}), I$ is irrigation $(\mathrm{cm}), E_{t}$ is evapotranspiration $(\mathrm{cm})$, and DP is deep percolation $(\mathrm{cm})$.

2.9. Leaching Depth Calculations. The length of the roots and shoots of onion seedlings ranged from 6 to $10 \mathrm{~cm}$ during transplanting. Thus, actual rooting depth of onion seedlings was selected as $10 \mathrm{~cm}$ at the time of transplant. The increase in rooting zone depth (RD) during the growing season was calculated as follows:

$$
\mathrm{RD}=\mathrm{RGC} \times \mathrm{GDD},
$$

where RGC is root growth coefficient equal to $0.0254 \mathrm{~cm}^{\circ} \mathrm{C}^{-1}$ [31]. Amount of available water content (AWC) stored in the rooting zone increased with an increase in depth of rooting zone and was calculated as

$$
\mathrm{AWC}=\mathrm{RD} \times \partial \theta,
$$

where $\partial \theta$ is change in water storage in the rooting zone during irrigation and can be calculated as

$$
\partial \theta=\theta_{f}-\theta_{i}
$$

where $\theta_{i}$ is the TDR-measured initial soil volumetric water content obtained by averaging the previous three $\theta$ readings before the start of irrigation, and $\theta_{f}$ is the TDR-measured final volumetric water content of soil (average of three $\theta$ ) 24 hours after the cessation of irrigation. The amount of leaching (LA) was determined as

$$
\mathrm{LA}=\mathrm{TWA}-\mathrm{AWC},
$$

where TWA is the total water received by a crop as irrigation or rainfall. A constraint applied to (9) was that if TWA < AWC, then $\mathrm{LA}=0$. The TDR sensor at the $20 \mathrm{~cm}$ depth recorded changes in $\theta$ with irrigation, but almost no change in $\theta$ was recorded at $50 \mathrm{~cm}$ depth throughout the growing season. Hence, soil at or below $50 \mathrm{~cm}$ was considered at field capacity (FC) during the entire growing season in both fields. The $\theta$ at FC was determined by collecting gravimetric soil samples $24 \mathrm{~h}$ after the cessation of irrigation at both fields, from 0 - to $110-\mathrm{cm}$ depth. For the furrow-irrigated field, FC was $0.31 \pm 0.02 \mathrm{~cm}^{3} \mathrm{~cm}^{-3}$ for the 0 - to $60-\mathrm{cm}$ depth and $0.18 \pm 0.03 \mathrm{~cm}^{3} \mathrm{~cm}^{-3}$ for depths greater than $60 \mathrm{~cm}$. For the drip-irrigated field, FC was $0.31 \pm 0.04 \mathrm{~cm}^{3} \mathrm{~cm}^{-3}$ for the 0 to $85-\mathrm{cm}$ depth and $0.18 \pm 0.05 \mathrm{~cm}^{3} \mathrm{~cm}^{-3}$ for depths greater than $85 \mathrm{~cm}$. The leaching depths in the upper $60 \mathrm{~cm}$ of the furrow-irrigated field and upper $85 \mathrm{~cm}$ of the drip-irrigated soil profile were calculated as

$$
\text { Leaching Depth }=\frac{\text { LA }}{0.31} \text {. }
$$

Similarly, the leaching depths below $60 \mathrm{~cm}$ in the furrowirrigated field and below $85 \mathrm{~cm}$ in the drip-irrigated field were calculated as

$$
\text { Leaching Depth }=\frac{\mathrm{LA}}{0.18} \text {. }
$$

The cumulative leaching depth below the rooting zone was obtained by adding leaching depths for each irrigation application. It was supposed that the first irrigation only saturated the upper $10 \mathrm{~cm}$ of the soil. A piston flow approach was adopted in both the fields to calculate the leaching depth of $\mathrm{N}$ fertilizer percolating to the deeper depths along with the irrigation water. The average $\mathrm{NO}_{3}-\mathrm{N}$ and chloride concentrations for the months fertilizer applications were made and were used to calculate the LF, IE, and amount of $\mathrm{NO}_{3}-\mathrm{N}$ loading below the rooting zone.

2.10. Statistical Analyses. As soil texture for the 0 to $50 \mathrm{~cm}$ soil profile also the rooting depth was similar in both fields, onion yield, leaching fractions, $\mathrm{N}$ use and application efficiencies in both fields were analyzed using the GLM (general linear model) procedure of SAS version 9.2 [32]. Statistical differences were evaluated at a probability level of $P \leq 0.05$.

\section{Results and Discussion}

3.1. Soil Properties. In the furrow-irrigated field, according to USDA soil classification, the top $60 \mathrm{~cm}$ of soil from 
the surface was a sandy clay loam and was sand below $60 \mathrm{~cm}$ (Table 1). The average BD of 0 to $60 \mathrm{~cm}$ depths was $1.4 \mathrm{~g} \mathrm{~cm}^{-3}$, and average $K_{s}$ was $2.33 \mathrm{~cm} \mathrm{~h}^{-1}$. The average soil $\mathrm{pH}$ and EC for the 0 to $60 \mathrm{~cm}$ depths were 7.4 and $2.0 \mathrm{dSm}^{-1}$ and were 8.0 and $0.77 \mathrm{dSm}^{-1}$ for depths greater than $60 \mathrm{~cm}$, respectively. For the 0 to $60 \mathrm{~cm}$ depths, average soil $\mathrm{OM}, \mathrm{P}$, and $\mathrm{K}$ were $0.43 \%, 11.6 \mathrm{mg} \mathrm{kg}^{-1}$, and $57.3 \mathrm{mg} \mathrm{kg}^{-1}$ and for depths greater than $60 \mathrm{~cm}$, these were $0.02 \%, 2.2 \mathrm{mg} \mathrm{kg}^{-1}$, and $29 \mathrm{mg} \mathrm{kg}^{-1}$, respectively (Table 2 ).

In the drip-irrigated field, the top $60 \mathrm{~cm}$ soil profile was classified as a sandy clay loam, 60 to $85 \mathrm{~cm}$ depth as silt loam, and below $85 \mathrm{~cm}$ as sand (Table 1). The average $\mathrm{BD}$ for the 0 to $60 \mathrm{~cm}$ depth was $1.4 \mathrm{~g} \mathrm{~cm}^{-3}$, and average $K_{s}$ was $2.1 \mathrm{~cm} \mathrm{~h}^{-1}$. The average soil $\mathrm{pH}$ and EC for the 0 to $60 \mathrm{~cm}$ depth were 7.6 and $2.0 \mathrm{dSm}^{-1}$, and for depths greater than $60 \mathrm{~cm}$ were 7.8 and $1.95 \mathrm{dSm}^{-1}$, respectively. The average soil $\mathrm{OM}, \mathrm{P}$, and $\mathrm{K}$ were $1.2 \%, 56.5 \mathrm{mg} \mathrm{kg}^{-1}$, and $119.2 \mathrm{mg} \mathrm{kg}^{-1}$ for 0 to $60 \mathrm{~cm}$ depth and $0.34 \%, 4.9 \mathrm{mg} \mathrm{kg}^{-1}$, and $62.5 \mathrm{mg} \mathrm{kg}^{-1}$ for depths greater than $60 \mathrm{~cm}$, respectively (Table 2). Consequently, the mineralization rate below $60 \mathrm{~cm}$ could be considered as negligible.

The soil texture of both fields was similar except at the 60 to $85 \mathrm{~cm}$ depth, at which drip-irrigated field contained more fine-textured soil than the furrow-irrigated field. The average soil EC for the 0 to $60 \mathrm{~cm}$ depths was equal or below the threshold of $2 \mathrm{dS} \mathrm{m}^{-1}$ [33] in both the fields. Consequently, yield and evapotranspiration were not influenced by salinity stress. The OM contents of each field was low $(\mathrm{OM}<1.8 \%)$; which is typical of the arid southern NM. The soil ESP and SAR values were well below the threshold levels of 13 and 15 , respectively [33], and there were no sodicity problems in either field. Up to $60-\mathrm{cm}$ depths, ESP, SAR, OM, P, and $\mathrm{K}$ contents were significantly higher $(P<0.05)$ in dripirrigated field than in furrow-irrigated field.

3.2. Onion Rooting Zone Depth. The majority of the onion roots were found in the 0 to $20 \mathrm{~cm}$ soil depth, with a maximum rooting depth of $48 \pm 2 \mathrm{~cm}$ during both the onion growing seasons. Hence, a maximum rooting depth of $50 \mathrm{~cm}$ was considered for both fields in estimating the leaching depth of $\mathrm{NO}_{3}-\mathrm{N}$ and water. The maximum onion rooting depth reported in the literature ranges from $30 \mathrm{~cm} \mathrm{[31]} \mathrm{to}$ $45 \mathrm{~cm} \mathrm{[3].}$

3.3. Soil Nitrate-N Content. During growing season 1 , average soil $\mathrm{NO}_{3}-\mathrm{N}$ content of the plow layer $(0-30 \mathrm{~cm})$ increased from $18.0 \mathrm{mg} \mathrm{kg}^{-1}$ in December 2006 to $21.6 \mathrm{mg} \mathrm{kg}^{-1}$ in January 2007 (Figure 1), which was equivalent to $14.8 \mathrm{~kg} \mathrm{NO}_{3}$ $\mathrm{N} \mathrm{ha}^{-1}$. This increase could only be due to the mineralization of the sudan grass incorporated prior to planting of the onion crop, because no fertilizer was applied at this stage in the furrow-irrigated field. It has been reported that $\mathrm{N}$ mineralization sharply increases as the air temperature increases from $13^{\circ} \mathrm{C}$ to $22^{\circ} \mathrm{C}$ [34]. Air temperature in the experimental field sites was above $13^{\circ} \mathrm{C}$ for 21 days during December 2006 , ranging from $13^{\circ} \mathrm{C}$ to $22^{\circ} \mathrm{C}$, and for 15 days during January 2007 , ranging from $13^{\circ} \mathrm{C}$ to $20^{\circ} \mathrm{C}$. Thus, air temperature was favorable for mineralization.
The soil $\mathrm{NO}_{3}-\mathrm{N}$ concentration increased to $26.9 \mathrm{mg} \mathrm{kg}^{-1}$ soil in the 0 to $50 \mathrm{~cm}$ layer during February 2007, after the first fertilizer application was made on February 23, 2007, four days before the soil sample was collected. The average soil $\mathrm{NO}_{3}-\mathrm{N}$ concentration further increased to $43.1 \mathrm{mg} \mathrm{kg}^{-1}$ during March and $68.6 \mathrm{mg} \mathrm{kg}^{-1}$ during April in the 0 to $50 \mathrm{~cm}$ layer, as two fertilizer applications were made during March and three during April (Figure 1; Table 3). Bulb initiation started during early April 2007 and was completed by the end of June 2007. The $\mathrm{NO}_{3}-\mathrm{N}$ concentration in the upper 0 to $50 \mathrm{~cm}$ soil layer (maximum root zone depth) then decreased in May and June, the months of high $\mathrm{N}$ uptake by onion plants [35].

Similarly, in growing season 2, average soil $\mathrm{NO}_{3}-\mathrm{N}$ content $(0-50 \mathrm{~cm})$ increased from $8.8 \mathrm{mg} \mathrm{kg}^{-1}$ in September 2008 to $15.9 \mathrm{mg} \mathrm{kg}^{-1}$ in October 2008 that was due to the fertilizer application of $49.2 \mathrm{~kg} \mathrm{ha}^{-1}$ in October 2008 (Figure 1). The average soil $\mathrm{NO}_{3}-\mathrm{N}$ content decreased to $9.9 \mathrm{mg} \mathrm{kg}^{-1}$ in January 2009 due to winter irrigation leaching as no fertilizer was applied during November and December 2008 and January 2009. The fertilizer was applied at a rate of $49.2 \mathrm{~kg} \mathrm{Nha}^{-1}$ per application during February (total of $49.2 \mathrm{~kg} \mathrm{Nha}^{-1}$ ), March (total of 98.4), and April, 2009 (total of $98.4 \mathrm{~kg} \mathrm{Nha}^{-1}$, Table 3). The average soil $\mathrm{NO}_{3}$ $\mathrm{N}$ content increased until it reached $45.3 \mathrm{mg} \mathrm{kg}^{-1}$ during April, 2009 and then a decreasing trend was observed in soil $\mathrm{NO}_{3}-\mathrm{N}$ content until harvesting of the crop. In general, soil $\mathrm{NO}_{3}-\mathrm{N}$ concentration was higher in the rooting zone than below it throughout the sampling period during both the growing seasons (Figure 1). Theoretically, $\mathrm{NO}_{3}$ $\mathrm{N}$ concentrations should be zero below the rooting zone, with all applied $\mathrm{N}$ taken up by the crop. The soil water $\mathrm{NO}_{3}-\mathrm{N}$ concentration, calculated by dividing soil $\mathrm{NO}_{3}-\mathrm{N}$ concentration by water content, was $105.2 \mathrm{mg} \mathrm{L}^{-1}$ during growing season 1 whereas it was $97.4 \mathrm{mg} \mathrm{L}^{-1}$ during growing season 2 below the crop rooting zone depth. This nitrogen can leach into the groundwater unless denitrification occurs within the capillary fringe zone just above the water table.

In the drip-irrigated field, the sequence of fertilizer applications was different and the number of fertilizer applications was also higher but the amount applied at each application was less for the drip- than the furrow-irrigated field. During growing season 1 , average soil $\mathrm{NO}_{3}-\mathrm{N}$ concentration increased from $11.8 \mathrm{mg} \mathrm{kg}^{-1}$ during December 2006 to $26.1 \mathrm{mg} \mathrm{kg}^{-1}$ during January 2007 in the plow layer $\left(0-30 \mathrm{~cm}\right.$ ), amounting to $60.1 \mathrm{~kg} \mathrm{NO}_{3}-\mathrm{N} \mathrm{ha}^{-1}$ (Figure 2). The $51.1 \mathrm{~kg} \mathrm{Nha}^{-1}$ came from the fertilizer application in January, and the rest was likely from the mineralization of sudan grass. The $\mathrm{NO}_{3}-\mathrm{N}$ concentration decreased for the 0 to $50 \mathrm{~cm}$ profile due to two rain events in February. The $\mathrm{NO}_{3}$ $\mathrm{N}$ increased to $25.8 \mathrm{mg} \mathrm{kg}^{-1}$ in the 0 to $50 \mathrm{~cm}$ soil profile during March primarily due to two applications of fertilizer. No fertilizer was applied during April, and that resulted in an attendant decrease in the soil $\mathrm{NO}_{3}-\mathrm{N}$ at almost all depths except 30 to $40 \mathrm{~cm}$ and 40 to $60 \mathrm{~cm}$. Soil $\mathrm{NO}_{3}-\mathrm{N}$ increased at all the depths within the 0 to $110 \mathrm{~cm}$ soil profile due to the 
TABLE 1: Mean and standard errors for soil physical properties of onion fields under furrow- and drip-irrigation systems in NM in 2006.

\begin{tabular}{|c|c|c|c|c|c|c|c|}
\hline $\begin{array}{l}\text { Irrigation } \\
\text { System }\end{array}$ & $\begin{array}{c}\text { Depth } \\
\mathrm{cm}\end{array}$ & Sand \% & Silt \% & Clay \% & Soil type & $\mathrm{BD} \mathrm{g} / \mathrm{cm}^{3}$ & $K_{s} \mathrm{~cm} / \mathrm{hr}$ \\
\hline \multirow{6}{*}{$\begin{array}{l}\text { Furrow } \\
\text { irrigated }\end{array}$} & $0-10$ & $56.5 \pm 0.00$ & $22.8 \pm 0.35$ & $20.7 \pm 0.35$ & Sandy clay loam & $1.3 \pm 0.02$ & $1.92 \pm 0.20$ \\
\hline & $10-30$ & $53.5 \pm 0.35$ & $25.6 \pm 0.53$ & $20.9 \pm 0.18$ & Sandy clay loam & $1.4 \pm 0.04$ & $2.02 \pm 0.22$ \\
\hline & $30-40$ & $52.3 \pm 0.18$ & $27.5 \pm 0.18$ & $20.2 \pm 0.00$ & Sandy clay loam & $1.4 \pm 0.05$ & $2.13 \pm 0.34$ \\
\hline & $40-60$ & $54.8 \pm 0.71$ & $25.2 \pm 0.71$ & $20.0 \pm 0.00$ & Sandy clay loam & $1.5 \pm 0.13$ & $3.23 \pm 1.10$ \\
\hline & $60-85$ & $90.3 \pm 1.94$ & $5.5 \pm 1.59$ & $4.2 \pm 0.35$ & Sand & - & - \\
\hline & $85-110$ & $95.8 \pm 0.00$ & $1.0 \pm 0.00$ & $3.2 \pm 0.00$ & Sand & - & - \\
\hline \multirow{6}{*}{$\begin{array}{l}\text { Drip } \\
\text { irrigated }\end{array}$} & $0-10$ & $50.8 \pm 0.35$ & $27.0 \pm 0.35$ & $22.2 \pm 0.00$ & Sandy clay loam & $1.2 \pm 0.03$ & $1.52 \pm 0.42$ \\
\hline & $10-30$ & $49.8 \pm 0.00$ & $27.0 \pm 0.00$ & $23.2 \pm 0.00$ & Sandy clay loam & $1.4 \pm 0.06$ & $1.43 \pm 0.20$ \\
\hline & $30-40$ & $46.8 \pm 1.77$ & $34.0 \pm 2.83$ & $19.2 \pm 1.06$ & Sandy clay loam & $1.4 \pm 0.13$ & $1.34 \pm 0.23$ \\
\hline & $40-60$ & $55.3 \pm 1.24$ & $24.3 \pm 0.35$ & $20.4 \pm 1.59$ & Sandy clay loam & $1.4 \pm 0.05$ & $4.09 \pm 0.9$ \\
\hline & $60-85$ & $31.8 \pm 4.24$ & $55.0 \pm 3.54$ & $13.2 \pm 0.71$ & Silt loam & - & - \\
\hline & $85-110$ & $88.2 \pm 1.13$ & $7.8 \pm 0.55$ & $4.0 \pm 0.22$ & Sand & - & - \\
\hline
\end{tabular}

BD: bulk density, $K_{s}$ : saturated hydraulic conductivity, and —: value not determined.

TAble 2: Soil chemical properties of two onion fields at the Plant Science Research Center (PSRC) and Fabian Garcia Research Center (FGRC) in NM in 2006.

\begin{tabular}{|c|c|c|c|c|c|c|c|c|}
\hline $\begin{array}{l}\text { Irrigation } \\
\text { system }\end{array}$ & Depth $\mathrm{cm}$ & $\mathrm{pH}$ & $\mathrm{EC}_{e} \mathrm{dS} / \mathrm{m}$ & SAR & ESP \% & OM \% & P ppm & $\mathrm{K}$ ppm \\
\hline \multirow{6}{*}{$\begin{array}{l}\text { Furrow } \\
\text { irrigated }\end{array}$} & $0-10$ & 7.3 & 2.10 & 3.54 & 3.80 & 0.58 & 16.70 & 83.0 \\
\hline & $10-30$ & 7.3 & 1.81 & 1.97 & 1.60 & 0.61 & 17.40 & 61.0 \\
\hline & $30-40$ & 7.4 & 1.89 & 1.38 & 0.80 & 0.48 & 9.90 & 51.0 \\
\hline & $40-60$ & 7.5 & 2.19 & 1.56 & 1.00 & 0.04 & 2.30 & 34.0 \\
\hline & $60-85$ & 7.8 & 1.02 & 2.00 & 1.70 & 0.03 & 2.80 & 32.0 \\
\hline & $85-110$ & 8.2 & 0.51 & 2.52 & 2.40 & 0.00 & 1.50 & 26.0 \\
\hline \multirow{6}{*}{$\begin{array}{l}\text { Drip } \\
\text { irrigated }\end{array}$} & $0-10$ & 7.7 & 2.31 & 3.52 & 3.80 & 1.44 & 62.50 & 137.0 \\
\hline & $10-30$ & 7.6 & 1.80 & 3.48 & 3.70 & 1.38 & 54.60 & 118.0 \\
\hline & $30-40$ & 7.5 & 2.33 & 3.88 & 4.30 & 1.67 & 88.90 & 138.0 \\
\hline & $40-60$ & 7.6 & 1.59 & 3.11 & 3.20 & 0.61 & 19.90 & 84.0 \\
\hline & $60-85$ & 7.7 & 1.85 & 3.14 & 3.30 & 0.43 & 7.20 & 79.00 \\
\hline & $85-110$ & 7.8 & 2.04 & 4.19 & 4.70 & 0.24 & 2.60 & 46.00 \\
\hline
\end{tabular}

$\mathrm{EC}_{e}$ : electrical conductivity of saturated extract, SAR: sodium adsorption ratio, ESP: exchangeable sodium percentage, OM: organic matter, P: phosphorous, and $\mathrm{K}$ : potassium.

fertilizer application of May 2007, and not much change in soil $\mathrm{NO}_{3}-\mathrm{N}$ was observed during June 2007.

A similar trend of soil $\mathrm{NO}_{3}-\mathrm{N}$ content was also observed during growing season 2 . The average soil $\mathrm{NO}_{3}-\mathrm{N}$ content $(0-50 \mathrm{~cm})$ increased from $11.2 \mathrm{mg} \mathrm{kg}^{-1}$ in February 2008 to $19.8 \mathrm{mg} \mathrm{kg}^{-1}$ in March 2008 that was due to the two fertilizer applications $\left(57.8 \mathrm{~kg} \mathrm{ha}^{-1}\right)$ in March 2008 . The average soil $\mathrm{NO}_{3}-\mathrm{N}$ content further increased to $22.8 \mathrm{mg} \mathrm{kg}^{-1}$ during April 2008 that was in response to another two fertilizer applications $\left(68 \mathrm{~kg} \mathrm{ha}^{-1}\right)$ in April, 2008. The average soil $\mathrm{NO}_{3}-\mathrm{N}$ content further increased to $27.3 \mathrm{mg} \mathrm{kg}^{-1}$ in May 2008 and $32 \mathrm{mg} \mathrm{kg}^{-1}$ in June 2008 in response to the two fertilizer applications in May $\left(64.4 \mathrm{~kg} \mathrm{ha}^{-1}\right)$ and another two in June (96.2 kg ha-1, Table 3). The soil $\mathrm{NO}_{3}-\mathrm{N}$ content decreased to $15.5 \mathrm{mg} \mathrm{kg}^{-1}$ in August 2008 due to plant uptake as well as $\mathrm{N}$ leaching as no fertilizer was applied during July and August 2008. An average soil water $\mathrm{NO}_{3}$ $\mathrm{N}$ concentration of $132.5 \mathrm{mg} \mathrm{L}^{-1}$ and $130.3 \mathrm{mg} \mathrm{L}^{-1}$ was estimated in the rooting zone of the crop during growing seasons 1 and 2, respectively. Similarly, soil water $\mathrm{NO}_{3}-\mathrm{N}$ concentration of $66.8 \mathrm{mg} \mathrm{L}^{-1}$ and $65.2 \mathrm{mg} \mathrm{L}^{-1}$ was estimated below rooting depth of the crop during growing seasons 1 and 2, respectively (Figure 2). Similar to the furrow-irrigated field, the $\mathrm{NO}_{3}-\mathrm{N}$ concentrations below rooting depths were much higher than the $\mathrm{NO}_{3}-\mathrm{N}$ levels of $10 \mathrm{mg} \mathrm{L}^{-1}$ recommended by the U.S. Environmental Protection Agency's drinking water standard [36].

3.4. Irrigation Water Front Depths. In the furrow-irrigated field, total water wetting front depth for the entire growing season was estimated at $213 \mathrm{~cm}$ during growing season 1 and $196 \mathrm{~cm}$ during growing season 2 (Table 4) from the 
TABLE 3: Type, date, and amount of N fertilizer applied in furrow- and drip-irrigated onion fields in NM in 2006-2009.

\begin{tabular}{|c|c|c|c|c|}
\hline Field & Irrigation system & Fertilizer type & Date of application & $\begin{array}{l}\text { Amount of application } \\
\left(\mathrm{kg} \mathrm{Nha}^{-1}\right)\end{array}$ \\
\hline \multirow{12}{*}{ PSRC } & \multirow{12}{*}{ Furrow irrigated } & \multirow{12}{*}{ URAN (26-0-0-6) } & $2 / 23 / 2007$ & 49.2 \\
\hline & & & $3 / 16 / 2007$ & 49.2 \\
\hline & & & $3 / 27 / 2007$ & 49.2 \\
\hline & & & $4 / 05 / 2007$ & 49.2 \\
\hline & & & $4 / 13 / 2007$ & 49.2 \\
\hline & & & $4 / 20 / 2007$ & 49.2 \\
\hline & & & $10 / 10 / 2008$ & 49.2 \\
\hline & & & $2 / 24 / 2009$ & 49.2 \\
\hline & & & $3 / 12 / 2009$ & 49.2 \\
\hline & & & $3 / 24 / 2009$ & 49.2 \\
\hline & & & $4 / 14 / 2009$ & 49.2 \\
\hline & & & $4 / 26 / 2009$ & 49.2 \\
\hline \multirow{16}{*}{ FGRC } & \multirow{16}{*}{ Drip irrigated } & \multirow{16}{*}{ URAN (26-0-0-6) } & $11 / 9 / 2006$ & 17.9 \\
\hline & & & $11 / 18 / 2006$ & 23.9 \\
\hline & & & $12 / 16 / 2006$ & 23.9 \\
\hline & & & $1 / 13 / 2007$ & 51.1 \\
\hline & & & $2 / 10 / 2007$ & 36.5 \\
\hline & & & $3 / 27 / 2007$ & 31.8 \\
\hline & & & $3 / 30 / 2007$ & 47.8 \\
\hline & & & $5 / 05 / 2007$ & 59.0 \\
\hline & & & $3 / 17 / 2008$ & 24.6 \\
\hline & & & $3 / 25 / 2008$ & 33.2 \\
\hline & & & $4 / 14 / 2008$ & 46.0 \\
\hline & & & $4 / 28 / 2008$ & 22.0 \\
\hline & & & $5 / 07 / 2008$ & 36.0 \\
\hline & & & $5 / 22 / 2008$ & 28.4 \\
\hline & & & $6 / 18 / 2008$ & 58.0 \\
\hline & & & $6 / 30 / 2008$ & 38.2 \\
\hline
\end{tabular}

PSRC: Plant Science Research Center, FGRC: Fabian Garcia Research Center; URAN: Urea ammonium nitrate.

soil surface, with average water wetting front velocity of $0.89 \mathrm{~cm} \mathrm{day}^{-1}$ during growing season 1 and $0.78 \mathrm{~cm} \mathrm{day}^{-1}$ in growing season 2. The $\mathrm{NO}_{3}-\mathrm{N}$ front depth was estimated at $149 \mathrm{~cm}$, with an average $\mathrm{NO}_{3}-\mathrm{N}$ front velocity of $1.18 \mathrm{~cm} \mathrm{day}^{-1}$ in growing season 1 whereas $\mathrm{NO}_{3}-\mathrm{N}$ front depth was $196 \mathrm{~cm}$, with average $\mathrm{NO}_{3}-\mathrm{N}$ front velocity of $0.82 \mathrm{~cm} \mathrm{day}^{-1}$ in growing season 2. Although $\mathrm{NO}_{3}-\mathrm{N}$ moves with water, the water wetting front depth was greater than the $\mathrm{N}$ front depth during both the growing seasons because six water applications were made beginning November 2006, before the first $\mathrm{N}$ fertilizer was applied during February 2007 in growing season 1. Similarly, water application was started on September, 2008 and first $\mathrm{N}$ fertilizer application was made on October, 2008 in growing season 2 and piston flow was the only mechanism considered for solute transport (Table 4).

In the drip-irrigated field, the depth of the water wetting front was estimated at $147 \mathrm{~cm}$ (Tables 5(a) and 5(b)), with average water wetting front velocity of $0.58 \mathrm{~cm} \mathrm{day}^{-1}$ in growing season 1 whereas the estimated depth of water wetting front was $105 \mathrm{~cm}$ (Tables 5(a) and 5(b)), with average water wetting front velocity of $0.67 \mathrm{~cm} \mathrm{day}^{-1}$ in growing season 2 . The $\mathrm{NO}_{3}-\mathrm{N}$ front depth was estimated at $86 \mathrm{~cm}$, with average $\mathrm{NO}_{3}-\mathrm{N}$ front velocity of $0.41 \mathrm{~cm} \mathrm{day}^{-1}$ in growing season 1 whereas estimated depth of $\mathrm{NO}_{3}-\mathrm{N}$ front was $87 \mathrm{~cm}$, with average $\mathrm{NO}_{3}-\mathrm{N}$ front velocity of $0.63 \mathrm{~cm} \mathrm{day}^{-1}$ in growing season 2 . Similar to the furrowirrigated field, the water wetting front was higher than the $\mathrm{NO}_{3}-\mathrm{N}$ front depth because the water application was started earlier than $\mathrm{N}$ fertilizer application.

The assumption that wetting and $\mathrm{NO}_{3}-\mathrm{N}$ fronts move at the same velocity may not be valid under field conditions. The $\mathrm{NO}_{3}-\mathrm{N}$ flow velocity can be lower than the wetting front velocity if $\mathrm{NO}_{3}-\mathrm{N}$ adsorption was taking place during the transport through the soil profile. In the case of anion exclusion, the $\mathrm{NO}_{3}-\mathrm{N}$ flow velocity could be higher than the wetting front velocity, and deeper leaching of $\mathrm{NO}_{3}-\mathrm{N}$ can be observed under such conditions [37]. 
TABLE 4: Date of irrigation, total amount of water applied (TWA), initial $\left(\theta_{i}\right)$ and final $\left(\theta_{f}\right)$ volumetric water content, rooting depth (RD), available water content (AWC), amount of leaching (LA), depth of leaching (LAD), cumulative leaching below the rooting zone depth (CLRBRZD), and depth of water front (DWF) during two onion growing seasons (2006-09) in a furrow-irrigated onion field in NM.

\begin{tabular}{|c|c|c|c|c|c|c|c|c|c|}
\hline $\begin{array}{l}\text { Date of } \\
\text { Irrigation }\end{array}$ & TWA cm & $\begin{array}{c}\theta_{i} \\
\mathrm{~cm}^{3} \mathrm{~cm}^{-3}\end{array}$ & $\begin{array}{c}\theta_{f} \\
\mathrm{~cm}^{3} \mathrm{~cm}^{-3}\end{array}$ & $\mathrm{RD} \mathrm{cm}$ & AWC cm & $\mathrm{LA} \mathrm{cm}$ & $\mathrm{LAD} \mathrm{cm}$ & $\begin{array}{c}\text { CLRBRZD } \\
\mathrm{cm}\end{array}$ & DWF cm \\
\hline $11 / 2 / 2006$ & 7.76 & 0.11 & 0.31 & 10.0 & \multicolumn{3}{|c|}{ Bring root zone to field capacity } & & \\
\hline $11 / 17 / 2006$ & 4.39 & 0.23 & 0.30 & 10.0 & 0.69 & 3.71 & 12.0 & 12.0 & 22.0 \\
\hline $11 / 29 / 2006$ & 4.39 & 0.24 & 0.30 & 10.0 & 0.67 & 3.72 & 12.0 & 24.0 & 34.0 \\
\hline $12 / 15 / 2007$ & 4.39 & 0.24 & 0.31 & 10.0 & 0.71 & 3.69 & 11.9 & 35.9 & 46 \\
\hline $1 / 8 / 2007$ & 4.09 & 0.23 & 0.31 & 10.0 & 0.77 & 3.32 & 10.7 & 46.6 & 57 \\
\hline $2 / 9 / 2007$ & 3.85 & 0.23 & 0.31 & 10.0 & 0.75 & 3.10 & 17.2 & 63.8 & 74 \\
\hline $2 / 23 / 2007$ & 3.55 & 0.24 & 0.30 & 10.0 & 0.57 & 2.98 & 16.5 & 80.4 & 90 \\
\hline $3 / 6 / 2007$ & 4.20 & 0.21 & 0.32 & 10.0 & 1.05 & 3.15 & 17.5 & 97.9 & 108 \\
\hline $3 / 16 / 2007$ & 4.14 & 0.22 & 0.32 & 12.7 & 1.28 & 2.86 & 15.9 & 113.7 & 124 \\
\hline $3 / 27 / 2007$ & 5.12 & 0.20 & 0.31 & 17.8 & 1.96 & 3.16 & 17.6 & 131.3 & 141 \\
\hline $4 / 5 / 2007$ & 4.70 & 0.22 & 0.32 & 22.9 & 2.29 & 2.41 & 13.4 & 144.7 & 155 \\
\hline $4 / 13 / 2007$ & 4.14 & 0.20 & 0.32 & 27.9 & 3.38 & 0.76 & 4.2 & 148.9 & 159 \\
\hline $4 / 20 / 2007$ & 4.91 & 0.21 & 0.31 & 30.5 & 3.05 & 1.86 & 10.4 & 159.3 & 169 \\
\hline $5 / 12 / 2007$ & 5.04 & 0.21 & 0.32 & 35.6 & 3.91 & 1.13 & 6.3 & 165.6 & 176 \\
\hline $5 / 25 / 2007$ & 4.45 & 0.21 & 0.31 & 38.1 & 3.81 & 0.64 & 3.5 & 169.1 & 179 \\
\hline $6 / 1 / 2007$ & 6.12 & 0.20 & 0.31 & 45.7 & 5.02 & 1.10 & 6.1 & 175.2 & 185 \\
\hline $6 / 7 / 2007$ & 6.10 & 0.21 & 0.31 & 45.7 & 4.63 & 1.47 & 8.2 & 183.3 & 193 \\
\hline $6 / 19 / 2007$ & 6.80 & 0.20 & 0.31 & 45.7 & 5.03 & 1.77 & 9.8 & 193.2 & 203 \\
\hline $6 / 29 / 2007$ & 6.78 & 0.19 & 0.30 & 45.7 & 4.97 & 1.81 & 10.1 & 203.2 & 213 \\
\hline \multicolumn{10}{|c|}{ 2008-2009 } \\
\hline $9 / 25 / 2008$ & 5.8 & 0.12 & 0.33 & 10.0 & 2.10 & 3.66 & 11.8 & & 10 \\
\hline $10 / 10 / 2008$ & 4.20 & 0.22 & 0.31 & 10.0 & 0.89 & 3.26 & 10.5 & 10.5 & 21 \\
\hline $10 / 24 / 2008$ & 3.24 & 0.24 & 0.29 & 10.0 & 0.57 & 2.67 & 8.6 & 19.1 & 29 \\
\hline $11 / 14 / 2008$ & 4.59 & 0.23 & 0.30 & 10.0 & 0.71 & 3.88 & 12.5 & 31.6 & 42 \\
\hline $11 / 21 / 2008$ & 4.15 & 0.24 & 0.32 & 10.0 & 0.77 & 3.38 & 10.9 & 42.5 & 53 \\
\hline $12 / 5 / 2008$ & 3.24 & 0.22 & 0.30 & 10.0 & 0.75 & 2.49 & 8.0 & 50.6 & 61 \\
\hline $12 / 18 / 2008$ & 3.31 & 0.23 & 0.30 & 10.0 & 0.67 & 2.64 & 8.5 & 59.1 & 69 \\
\hline $1 / 9 / 2009$ & 3.20 & 0.22 & 0.31 & 10.0 & 0.85 & 2.35 & 13.1 & 72.1 & 82 \\
\hline $2 / 11 / 2009$ & 3.12 & 0.22 & 0.30 & 12.7 & 1.03 & 2.09 & 11.6 & 83.8 & 94 \\
\hline $3 / 6 / 2009$ & 4.58 & 0.21 & 0.31 & 17.8 & 1.78 & 2.80 & 15.6 & 99.3 & 109 \\
\hline $3 / 20 / 2009$ & 4.66 & 0.21 & 0.31 & 22.9 & 2.29 & 2.29 & 12.7 & 112.1 & 122 \\
\hline $3 / 27 / 2009$ & 4.01 & 0.23 & 0.32 & 27.9 & 2.54 & 2.12 & 11.8 & 123.8 & 134 \\
\hline $4 / 3 / 2009$ & 4.81 & 0.22 & 0.32 & 30.5 & 3.05 & 0.96 & 5.3 & 129.2 & 139 \\
\hline $4 / 9 / 2009$ & 5.49 & 0.22 & 0.32 & 35.6 & 3.56 & 1.25 & 7.0 & 136.1 & 146 \\
\hline $4 / 17 / 2009$ & 5.91 & 0.20 & 0.30 & 38.1 & 3.81 & 1.68 & 9.3 & 145.5 & 155 \\
\hline $4 / 24 / 2009$ & 6.20 & 0.21 & 0.32 & 45.7 & 5.02 & 0.88 & 4.9 & 150.4 & 160 \\
\hline $5 / 1 / 2009$ & 6.78 & 0.22 & 0.33 & 45.7 & 5.08 & 1.12 & 6.2 & 156.6 & 167 \\
\hline $5 / 8 / 2009$ & 5.62 & 0.23 & 0.31 & 45.7 & 3.66 & 3.12 & 17.3 & 173.9 & 184 \\
\hline $5 / 15 / 2009$ & 6.53 & 0.22 & 0.33 & 45.7 & 5.03 & 0.59 & 3.3 & 177.2 & 187 \\
\hline $5 / 27 / 2009$ & 5.44 & 0.19 & 0.31 & 45.7 & 5.49 & 1.04 & 5.8 & 183.0 & 193 \\
\hline $6 / 4 / 2009$ & 5.3 & 0.20 & 0.31 & 45.7 & 4.97 & 0.47 & 2.6 & 185.6 & 196 \\
\hline
\end{tabular}

3.5. Plant Nutrient Content and Onion Yield. In the furrowirrigated field, total $\mathrm{N}$ concentration in plant tissue was $1.68 \pm 0.003 \%$ of the total dry onion biomass in growing season 1 whereas it was $1.7 \pm 0.004 \%$ in growing season 2 .
However, in the drip-irrigated field, total $\mathrm{N}$ concentration in plant tissue was $1.65 \pm 0.003 \%$ and $1.63 \pm 0.003 \%$ of the total biomass of dry onion in growing seasons 1 and 2, respectively. The chloride concentration in the plant tissue 
TABLe 5: (a) Date of irrigation, total amount of water applied (TWA), initial $\left(\theta_{i}\right)$ and final $\left(\theta_{f}\right)$ volumetric water content, rooting depth (RD), available water content (AWC), amount of leaching (LA), depth of leaching (LAD), cumulative leaching below root zone depth (CLRBRZD), and depth of water front (DWF) during onion growing season 1 (2006-07) in a drip-irrigated onion field in NM. (b) Date of irrigation, total amount of water applied (TWA), initial $\left(\theta_{i}\right)$ and final $\left(\theta_{f}\right)$ volumetric water content, rooting depth (RD), available water content (AWC), amount of leaching (LA), depth of leaching (LAD), cumulative leaching below root zone depth (CLRBRZD), and depth of water front (DWF) during onion growing season 2 (2008) in a drip-irrigated onion field in NM.

(a)

\begin{tabular}{|c|c|c|c|c|c|c|c|c|c|}
\hline $\begin{array}{l}\text { Date of } \\
\text { irrigation }\end{array}$ & TWA cm & $\begin{array}{c}\theta_{i} \\
\mathrm{~cm}^{3} \mathrm{~cm}^{-3}\end{array}$ & $\begin{array}{c}\theta_{f} \\
\mathrm{~cm}^{3} \mathrm{~cm}^{-3}\end{array}$ & $\mathrm{RD} \mathrm{cm}$ & AWC cm & LA cm & $\mathrm{LAD} \mathrm{cm}$ & $\begin{array}{c}\text { CLRBRZD } \\
\mathrm{cm}\end{array}$ & DWF cm \\
\hline $9 / 29 / 2006$ & 3.43 & 0.16 & 0.31 & 10.0 & \multicolumn{3}{|c|}{ Bring root zone to field capacity } & & 10 \\
\hline $9 / 30 / 2006$ & 4.20 & 0.29 & 0.32 & 10.0 & 0.35 & 3.85 & 12.4 & 12.4 & 22 \\
\hline $10 / 3 / 2006$ & 4.69 & 0.25 & 0.32 & 10.0 & 0.70 & 3.99 & 12.9 & 25.3 & 35 \\
\hline $10 / 5 / 2006$ & 3.80 & 0.28 & 0.31 & 10.0 & 0.35 & 3.45 & 11.1 & 36.4 & 46 \\
\hline $10 / 6 / 2006$ & 2.09 & 0.29 & 0.32 & 10.0 & 0.34 & 1.76 & 5.7 & 42.1 & 52 \\
\hline $10 / 22 / 2006$ & 4.61 & 0.23 & 0.32 & 10.0 & 0.87 & 3.74 & 12.1 & 54.2 & 64 \\
\hline $10 / 30 / 2006$ & 2.09 & 0.25 & 0.31 & 10.0 & 0.61 & 1.48 & 4.8 & 58.9 & 69 \\
\hline $10 / 31 / 2006$ & 0.83 & 0.29 & 0.30 & 10.0 & 0.17 & 0.66 & 2.1 & 61.0 & 71 \\
\hline $11 / 9 / 2006$ & 1.95 & 0.23 & 0.31 & 10.0 & 0.78 & 1.17 & 3.8 & 64.8 & 75 \\
\hline $11 / 18 / 2006$ & 1.95 & 0.24 & 0.32 & 10.0 & 0.78 & 1.17 & 3.8 & 68.6 & 79 \\
\hline $11 / 25 / 2006$ & 2.04 & 0.25 & 0.32 & 10.0 & 0.70 & 1.34 & 4.3 & 72.9 & 83 \\
\hline $12 / 3 / 2006$ & 1.02 & 0.26 & 0.30 & 10.0 & 0.36 & 0.66 & 2.1 & 75.0 & 85 \\
\hline $12 / 8 / 2006$ & 1.01 & 0.26 & 0.30 & 10.0 & 0.36 & 0.65 & 3.6 & 78.6 & 89 \\
\hline $12 / 16 / 2006$ & 1.77 & 0.27 & 0.30 & 10.0 & 0.26 & 1.51 & 8.4 & 87.0 & 97 \\
\hline $12 / 24 / 2006$ & 0.80 & 0.27 & 0.30 & 10.0 & 0.35 & 0.45 & 2.5 & 89.5 & 100 \\
\hline $1 / 13 / 2007$ & 1.13 & 0.26 & 0.32 & 10.0 & 0.61 & 0.52 & 2.9 & 92.4 & 103 \\
\hline $2 / 4 / 2007$ & 1.01 & 0.26 & 0.31 & 10.0 & 0.52 & 0.49 & 2.7 & 95.1 & 105 \\
\hline $2 / 10 / 2007$ & 1.65 & 0.25 & 0.32 & 10.0 & 0.70 & 0.95 & 5.3 & 100.4 & 111 \\
\hline $2 / 20 / 2007$ & 0.80 & 0.26 & 0.30 & 10.0 & 0.35 & 0.45 & 2.5 & 102.9 & 113 \\
\hline $3 / 2 / 2007$ & 1.64 & 0.25 & 0.32 & 12.7 & 1.01 & 0.63 & 3.5 & 106.4 & 117 \\
\hline $3 / 10 / 2007$ & 1.43 & 0.25 & 0.29 & 17.8 & 0.62 & 0.81 & 4.5 & 110.9 & 121 \\
\hline $3 / 14 / 2007$ & 1.29 & 0.26 & 0.30 & 22.9 & 0.80 & 0.49 & 2.7 & 113.7 & 124 \\
\hline $3 / 19 / 2007$ & 1.32 & 0.27 & 0.31 & 27.9 & 1.15 & 0.17 & 1.0 & 114.7 & 125 \\
\hline $3 / 23 / 2007$ & 1.53 & 0.27 & 0.30 & 30.5 & 0.80 & 0.73 & 4.1 & 118.7 & 129 \\
\hline $3 / 27 / 2007$ & 1.87 & 0.27 & 0.30 & 35.6 & 1.24 & 0.63 & 3.5 & 122.2 & 132 \\
\hline $3 / 30 / 2007$ & 1.35 & 0.28 & 0.31 & 38.1 & 1.50 & 0.00 & 0.0 & 122.2 & 132 \\
\hline $4 / 4 / 2007$ & 2.28 & 0.27 & 0.31 & 45.7 & 2.24 & 0.04 & 0.2 & 122.4 & 133 \\
\hline $4 / 8 / 2007$ & 0.99 & 0.27 & 0.29 & 45.7 & 1.12 & 0.00 & 0.0 & 122.4 & 133 \\
\hline $4 / 11 / 2007$ & 2.02 & 0.27 & 0.31 & 45.7 & 1.99 & 0.03 & 0.2 & 122.6 & 133 \\
\hline $4 / 16 / 2007$ & 2.54 & 0.27 & 0.31 & 45.7 & 2.25 & 0.29 & 1.6 & 124.2 & 134 \\
\hline $4 / 23 / 2007$ & 1.89 & 0.26 & 0.30 & 45.7 & 1.86 & 0.03 & 0.2 & 124.4 & 134 \\
\hline $4 / 24 / 2007$ & 1.35 & 0.30 & 0.32 & 45.7 & 1.14 & 0.21 & 1.2 & 125.6 & 136 \\
\hline $4 / 26 / 2007$ & 1.94 & 0.29 & 0.32 & 45.7 & 1.81 & 0.13 & 0.7 & 126.3 & 136 \\
\hline $5 / 5 / 2007$ & 3.22 & 0.25 & 0.31 & 45.7 & 3.09 & 0.13 & 0.7 & 127.1 & 137 \\
\hline $5 / 11 / 2007$ & 1.31 & 0.27 & 0.30 & 45.7 & 1.19 & 0.12 & 0.7 & 127.7 & 138 \\
\hline $5 / 14 / 2007$ & 1.49 & 0.26 & 0.29 & 45.7 & 1.19 & 0.30 & 1.7 & 129.4 & 139 \\
\hline $5 / 21 / 2007$ & 2.70 & 0.25 & 0.30 & 45.7 & 2.39 & 0.31 & 1.7 & 131.1 & 141 \\
\hline $5 / 24 / 2007$ & 0.30 & 0.27 & 0.30 & 45.7 & 1.25 & 0.00 & 0.0 & 131.1 & 141 \\
\hline $5 / 25 / 2007$ & 2.05 & 0.28 & 0.31 & 45.7 & 1.59 & 0.46 & 2.5 & 133.7 & 144 \\
\hline $5 / 31 / 2007$ & 2.02 & 0.25 & 0.30 & 45.7 & 1.99 & 0.03 & 0.2 & 133.8 & 144 \\
\hline
\end{tabular}


(a) Continued.

\begin{tabular}{lccccccccc}
\hline $\begin{array}{l}\text { Date of } \\
\text { irrigation }\end{array}$ & TWA cm & $\begin{array}{c}\theta_{i} \\
\mathrm{~cm}^{3} \mathrm{~cm}^{-3}\end{array}$ & $\begin{array}{c}\theta_{f} \\
\mathrm{~cm}^{3} \mathrm{~cm}^{-3}\end{array}$ & RD cm & AWC cm & LA cm & LAD cm & $\begin{array}{c}\text { CLRBRZD } \\
\mathrm{cm}\end{array}$ & $\begin{array}{c}\text { DWF cm } \\
6 / 1 / 2007\end{array}$ \\
\hline 2.20 & 0.28 & 0.31 & 45.7 & 1.59 & 0.61 & 3.4 & 137.2 & 147 \\
$6 / 7 / 2007$ & 1.16 & 0.25 & 0.30 & 45.7 & 2.11 & 0.00 & 0.0 & 137.2 & 147 \\
\hline
\end{tabular}

(b)

\begin{tabular}{|c|c|c|c|c|c|c|c|c|c|}
\hline $\begin{array}{l}\text { Date of } \\
\text { irrigation }\end{array}$ & TWA cm & $\begin{array}{c}\theta_{i} \\
\mathrm{~cm}^{3} \mathrm{~cm}^{-3}\end{array}$ & $\begin{array}{c}\theta_{f} \\
\mathrm{~cm}^{3} \mathrm{~cm}^{-3}\end{array}$ & $\mathrm{RD} \mathrm{cm}$ & AWC cm & LA cm & $\mathrm{LAD} \mathrm{cm}$ & $\begin{array}{c}\text { CLRBRZD } \\
\mathrm{cm}\end{array}$ & DWF cm \\
\hline $3 / 1 / 2008$ & 3.43 & 0.16 & 0.31 & 10.0 & \multicolumn{3}{|c|}{ Bring root zone to field capacity } & & 10 \\
\hline $3 / 3 / 2008$ & 2.15 & 0.27 & 0.32 & 10.0 & 0.55 & 1.60 & 5.2 & 5.2 & 15 \\
\hline $3 / 6 / 2008$ & 3.06 & 0.26 & 0.33 & 10.0 & 0.70 & 2.36 & 7.6 & 12.8 & 23 \\
\hline $3 / 12 / 2008$ & 1.90 & 0.26 & 0.31 & 10.0 & 0.55 & 1.35 & 4.4 & 17.2 & 27 \\
\hline $3 / 17 / 2008$ & 1.79 & 0.28 & 0.32 & 10.0 & 0.44 & 1.36 & 4.4 & 21.6 & 32 \\
\hline $3 / 20 / 2008$ & 1.54 & 0.25 & 0.31 & 10.0 & 0.57 & 0.97 & 3.1 & 24.7 & 35 \\
\hline $3 / 25 / 2008$ & 2.19 & 0.24 & 0.30 & 10.0 & 0.61 & 1.58 & 5.1 & 29.8 & 40 \\
\hline $3 / 31 / 2008$ & 1.02 & 0.27 & 0.31 & 10.0 & 0.47 & 0.55 & 1.8 & 31.6 & 42 \\
\hline $4 / 3 / 2008$ & 1.72 & 0.24 & 0.31 & 10.0 & 0.68 & 1.04 & 3.3 & 34.9 & 45 \\
\hline $4 / 7 / 2008$ & 2.05 & 0.25 & 0.33 & 10.0 & 0.78 & 1.27 & 4.1 & 39.0 & 49 \\
\hline $4 / 9 / 2008$ & 1.62 & 0.26 & 0.32 & 10.0 & 0.60 & 1.02 & 3.3 & 42.3 & 52 \\
\hline $4 / 14 / 2008$ & 1.13 & 0.24 & 0.30 & 10.0 & 0.56 & 0.57 & 1.8 & 44.1 & 54 \\
\hline $4 / 17 / 2008$ & 0.91 & 0.27 & 0.29 & 10.0 & 0.23 & 0.68 & 2.2 & 46.3 & 56 \\
\hline $4 / 22 / 2008$ & 1.57 & 0.26 & 0.31 & 10.0 & 0.46 & 1.11 & 3.6 & 49.9 & 60 \\
\hline $4 / 25 / 2008$ & 1.15 & 0.26 & 0.30 & 10.0 & 0.45 & 0.70 & 2.3 & 52.2 & 62 \\
\hline $4 / 28 / 2008$ & 1.33 & 0.27 & 0.31 & 10.0 & 0.41 & 0.92 & 3.0 & 55.1 & 65 \\
\hline $5 / 1 / 2008$ & 1.21 & 0.27 & 0.32 & 10.0 & 0.52 & 0.69 & 2.2 & 57.3 & 67 \\
\hline $5 / 7 / 2008$ & 1.25 & 0.25 & 0.31 & 10.0 & 0.60 & 0.65 & 2.1 & 59.5 & 69 \\
\hline $5 / 12 / 2008$ & 1.20 & 0.25 & 0.31 & 10.0 & 0.55 & 0.65 & 2.1 & 61.6 & 72 \\
\hline $5 / 15 / 2008$ & 1.21 & 0.27 & 0.32 & 12.7 & 0.76 & 0.45 & 1.5 & 63.0 & 73 \\
\hline $5 / 20 / 2008$ & 1.23 & 0.25 & 0.30 & 17.8 & 0.80 & 0.43 & 1.4 & 64.4 & 74 \\
\hline $5 / 22 / 2008$ & 1.37 & 0.26 & 0.31 & 22.9 & 1.02 & 0.34 & 1.1 & 65.5 & 76 \\
\hline $5 / 26 / 2008$ & 1.41 & 0.26 & 0.31 & 27.9 & 1.43 & 0.00 & 0.0 & 65.5 & 76 \\
\hline $5 / 30 / 2008$ & 1.13 & 0.27 & 0.30 & 30.5 & 0.80 & 0.33 & 1.1 & 66.6 & 77 \\
\hline $6 / 3 / 2008$ & 1.32 & 0.26 & 0.30 & 35.6 & 1.59 & 0.00 & 0.0 & 66.6 & 77 \\
\hline $6 / 6 / 2008$ & 2.21 & 0.27 & 0.32 & 38.1 & 2.27 & 0.00 & 0.0 & 66.6 & 77 \\
\hline $6 / 10 / 2008$ & 2.34 & 0.26 & 0.33 & 45.7 & 3.61 & 0.00 & 0.0 & 66.6 & 77 \\
\hline $6 / 14 / 2008$ & 2.43 & 0.28 & 0.31 & 45.7 & 1.57 & 0.86 & 2.8 & 69.4 & 79 \\
\hline $6 / 18 / 2008$ & 2.06 & 0.26 & 0.32 & 45.7 & 2.90 & 0.00 & 0.0 & 69.4 & 79 \\
\hline $6 / 23 / 2008$ & 3.14 & 0.27 & 0.31 & 45.7 & 2.25 & 0.89 & 4.9 & 74.3 & 84 \\
\hline $6 / 27 / 2008$ & 1.71 & 0.26 & 0.31 & 45.7 & 2.32 & 0.00 & 0.0 & 74.3 & 84 \\
\hline $6 / 30 / 2008$ & 1.22 & 0.29 & 0.32 & 45.7 & 1.60 & 0.00 & 0.0 & 74.3 & 84 \\
\hline $7 / 3 / 2008$ & 2.45 & 0.28 & 0.32 & 45.7 & 2.26 & 0.19 & 1.0 & 75.4 & 85 \\
\hline $7 / 8 / 2008$ & 2.92 & 0.25 & 0.31 & 45.7 & 3.09 & 0.00 & 0.0 & 75.4 & 85 \\
\hline $7 / 14 / 2008$ & 1.71 & 0.25 & 0.30 & 45.7 & 2.11 & 0.00 & 0.0 & 75.4 & 85 \\
\hline $7 / 18 / 2008$ & 1.63 & 0.26 & 0.29 & 45.7 & 1.19 & 0.44 & 2.4 & 77.8 & 88 \\
\hline $7 / 22 / 2008$ & 2.52 & 0.26 & 0.30 & 45.7 & 1.93 & 0.59 & 3.3 & 81.1 & 91 \\
\hline $7 / 25 / 2008$ & 1.72 & 0.27 & 0.29 & 45.7 & 1.12 & 0.60 & 3.4 & 84.4 & 94 \\
\hline $7 / 29 / 2008$ & 2.55 & 0.27 & 0.31 & 45.7 & 2.05 & 0.50 & 2.8 & 87.2 & 97 \\
\hline $8 / 1 / 2008$ & 2.41 & 0.27 & 0.30 & 45.7 & 1.07 & 1.34 & 7.4 & 94.6 & 105 \\
\hline
\end{tabular}


TABLE 6: Mean and standard errors for $\mathrm{NO}_{3}-\mathrm{N}$, chloride, and water balance during two onion growing seasons (2006-09) in furrow-irrigated onion field in NM.

\begin{tabular}{|c|c|c|c|c|c|c|c|}
\hline & & \multicolumn{3}{|c|}{ Furrow-irrigated field (2006-07) } & \multicolumn{3}{|c|}{ Furrow-irrigated field (2008-09) } \\
\hline & & $\begin{array}{l}\text { Nitrate-N } \\
\left(\mathrm{kgha}^{-1}\right)\end{array}$ & $\begin{array}{l}\text { Chloride } \\
\left(\mathrm{kg} \mathrm{ha}^{-1}\right)\end{array}$ & Water $\mathrm{cm}$ & $\begin{array}{l}\text { Nitrate-N } \\
\left(\mathrm{kg} \mathrm{ha}^{-1}\right)\end{array}$ & $\begin{array}{l}\text { Chloride } \\
\left(\mathrm{kg} \mathrm{ha}^{-1}\right)\end{array}$ & Water $\mathrm{cm}$ \\
\hline 1 & Total applied & 295 & 522 & 95 & 295 & 530 & 100 \\
\hline 2 & Deep percolated ( $>50 \mathrm{~cm}$ depth) & $150 \pm 2.2$ & $331 \pm 2.7$ & $19 \pm 0.85$ & $145 \pm 0.5$ & $306 \pm 3.07$ & $22.3 \pm 1.0$ \\
\hline 3 & Crop uptake $\left({ }^{*} E_{t}\right)$ & $104 \pm 0.21$ & $78 \pm 0.20$ & $* 61 \pm 0.0$ & $106 \pm 0.1$ & $79 \pm 0.52$ & $* 62 \pm 0.0$ \\
\hline 4 & Before planting $(0-50 \mathrm{~cm}$ depth) & $94 \pm 1.7$ & $105 \pm 4.7$ & $3 \pm 0.24$ & $83.7 \pm 1.9$ & $87.2 \pm 1.9$ & $3 \pm 0.15$ \\
\hline 5 & After harvest (0-50 cm depth) & $134 \pm 2.9$ & $208 \pm 4.7$ & $10 \pm 0.53$ & $129.3 \pm 1.2$ & $224.2 \pm 1.9$ & $11 \pm 0.29$ \\
\hline 6 & Storage $(0-50 \mathrm{~cm}$ depth $)$ & $40 \pm 1.2$ & $102 \pm 8.2$ & $7 \pm 0.35$ & $45.6 \pm 2.6$ & $137 \pm 0.31$ & $8 \pm 0.43$ \\
\hline 7 & $\begin{array}{l}\text { Output (total loss, uptake, and } \\
\text { change; Rows } 2+3+6 \text { ) }\end{array}$ & $294 \pm 1.8$ & $512 \pm 6.9$ & $87 \pm 1.2$ & $297 \pm 3.1$ & $522 \pm 2.6$ & $95 \pm 0.62$ \\
\hline 8 & Mass balance error (Row 1-Row 7) & $1 \pm 1.8$ & $10 \pm 6.9$ & $8 \pm 1.2$ & $-2 \pm 3.1$ & $8 \pm 2.6$ & $8 \pm 0.62$ \\
\hline
\end{tabular}

TABLE 7: Mean and standard errors for $\mathrm{NO}_{3}-\mathrm{N}$, chloride, and water balance during two onion growing seasons (2006-08) in drip-irrigated onion field in NM.

\begin{tabular}{|c|c|c|c|c|c|c|c|}
\hline & & \multicolumn{3}{|c|}{ Drip-irrigated field (2006-07) } & \multicolumn{3}{|c|}{ Drip-irrigated field (2008) } \\
\hline & & $\begin{array}{l}\text { Nitrate-N } \\
\left(\mathrm{kg} \mathrm{ha}^{-1}\right)\end{array}$ & $\begin{array}{l}\text { Chloride } \\
\left(\mathrm{kg} \mathrm{ha}^{-1}\right)\end{array}$ & Water $\mathrm{cm}$ & $\begin{array}{l}\text { Nitrate-N } \\
\left(\mathrm{kg} \mathrm{ha}^{-1}\right)\end{array}$ & $\begin{array}{l}\text { Chloride } \\
\left(\mathrm{kg} \mathrm{ha}^{-1}\right)\end{array}$ & Water $\mathrm{cm}$ \\
\hline 1 & Total applied & 292 & 486 & 81 & 286 & 396 & 72 \\
\hline 2 & Deep percolated ( $>50 \mathrm{~cm}$ depth) & $79 \pm 6.9$ & $298 \pm 11.3$ & $14 \pm 1.77$ & $76 \pm 0.27$ & $245 \pm 5.6$ & $12.5 \pm 0.8$ \\
\hline 3 & Crop uptake $\left(E_{t}^{*}\right)$ & $112 \pm 0.20$ & $86 \pm 0.21$ & $56 \pm 0.0^{*}$ & $111 \pm 0.27$ & $84 \pm 0.32$ & $55 \pm 0.0^{*}$ \\
\hline 4 & Before planting $(0-50 \mathrm{~cm}$ depth $)$ & $69 \pm 3.5$ & $86 \pm 12.7$ & $3 \pm 0.18$ & $65 \pm 2.42$ & $78 \pm 4.3$ & $4 \pm 0.3$ \\
\hline 5 & After harvest (0-50 cm depth) & $159 \pm 5.5$ & $180 \pm 13.9$ & $9 \pm 0.29$ & $156 \pm 3.95$ & $139 \pm 7.3$ & $8 \pm 0.3$ \\
\hline 6 & Storage (0-50 cm depth) & $90 \pm 2.0$ & $94 \pm 10.0$ & $6 \pm 0.37$ & $91 \pm 2.38$ & $61 \pm 3.1$ & $4 \pm 0.4$ \\
\hline 7 & $\begin{array}{l}\text { Output (total loss, uptake, and } \\
\text { change; Rows } 2+3+6 \text { ) }\end{array}$ & $281 \pm 3.8$ & $477 \pm 9.7$ & $76 \pm 1.72$ & $278 \pm 2.12$ & $390 \pm 8.1$ & $71.5 \pm 0.5$ \\
\hline 8 & Mass balance error (Row 1-Row 7) & $11 \pm 3.8$ & $9 \pm 9.7$ & $5 \pm 1.72$ & $8 \pm 2.12$ & $6 \pm 8.1$ & $0.5 \pm 0.5$ \\
\hline
\end{tabular}

was $1.26 \pm 0.002 \%$ and $1.25 \pm 0.002 \%$ of the total biomass of dry onion for furrow-irrigated field in growing seasons 1 and 2 , respectively, and $1.24 \pm 0.002 \%$ in growing seasons 1 and 2 for drip-irrigated field. Since amount of chloride uptake by plants constitutes a very small proportion of the total chloride flux, chloride uptake makes a little difference $(<3 \%)$ in estimating the irrigation efficiencies [16].

In the furrow-irrigated field, onion yield on a wet basis was $45,120 \mathrm{~kg} \mathrm{ha}^{-1}$ in growing season 1 and $45,420 \mathrm{~kg} \mathrm{ha}^{-1}$ in growing season 2 with a moisture content of $90 \%$. The total dry onion biomass yield was $6210 \mathrm{~kg} \mathrm{ha}^{-1}$ and $6251 \mathrm{~kg} \mathrm{ha}^{-1}$ in growing seasons 1 and 2, respectively, in the furrowirrigated field.

The onion yield on the wet basis was $50,980 \mathrm{~kg} \mathrm{ha}^{-1}$ and $50,840 \mathrm{~kg} \mathrm{ha}^{-1}$ in growing seasons 1 and 2, respectively, in drip-irrigated field. These yields were significantly higher $(P<0.01)$ than those from the furrow-irrigated field during both the seasons. The total dry onion biomass yield was $6840 \mathrm{~kg} \mathrm{ha}^{-1}$ and $6800 \mathrm{~kg} \mathrm{ha}^{-1}$ in growing seasons 1 and 2, respectively. The yields were not significantly different $(P>$ 0.05 ) between the two growing seasons for either furrow- or drip-irrigated fields.
3.6. Nitrate- $\mathrm{N}$ and Chloride Ratio. In the furrow-irrigated field, within the rooting zone, the $\mathrm{NO}_{3}-\mathrm{N} / \mathrm{Cl}$ ratio was variable. This could be due to the mineralization of sudan grass and/or $\mathrm{N}$ uptake by the onion crop (Figure 3). Below the crop rooting zone, where no $\mathrm{N}$ uptake occurs, the average $\mathrm{NO}_{3}-\mathrm{N} / \mathrm{Cl}$ ratio was similar, and averages of $0.61,0.62$, 0.61 , and 0.62 were estimated during growing season 1 and $0.54,0.53,0.54$, and 0.54 during growing season 2 at 85-, 110-, 150- and 200-cm depths, respectively (Figure 3). These values showed that $\mathrm{NO}_{3}-\mathrm{N}$ distribution and $\mathrm{LF}$ were uniform throughout the growing seasons. They also showed that excess $\mathrm{N}$ was applied to meet the plant $\mathrm{N}$ needs throughout the growing seasons.

In the drip-irrigated field, the $\mathrm{NO}_{3}-\mathrm{N} / \mathrm{Cl}$ ratio in the entire soil profile was variable (Figure 3 ). The average $\mathrm{NO}_{3}$ $\mathrm{N} / \mathrm{Cl}$ ratio below rooting zone was $0.25,0.26,0.24$, and 0.25 during growing season 1 and $0.29,0.29,0.28$, and 0.29 during growing season 2 at 85-, 110-, 150-, and 200-cm depths, respectively. These values again showed excess but uniform $\mathrm{NO}_{3}-\mathrm{N}$ distribution and $\mathrm{LF}$ during both the growing seasons in drip-irrigated field. 

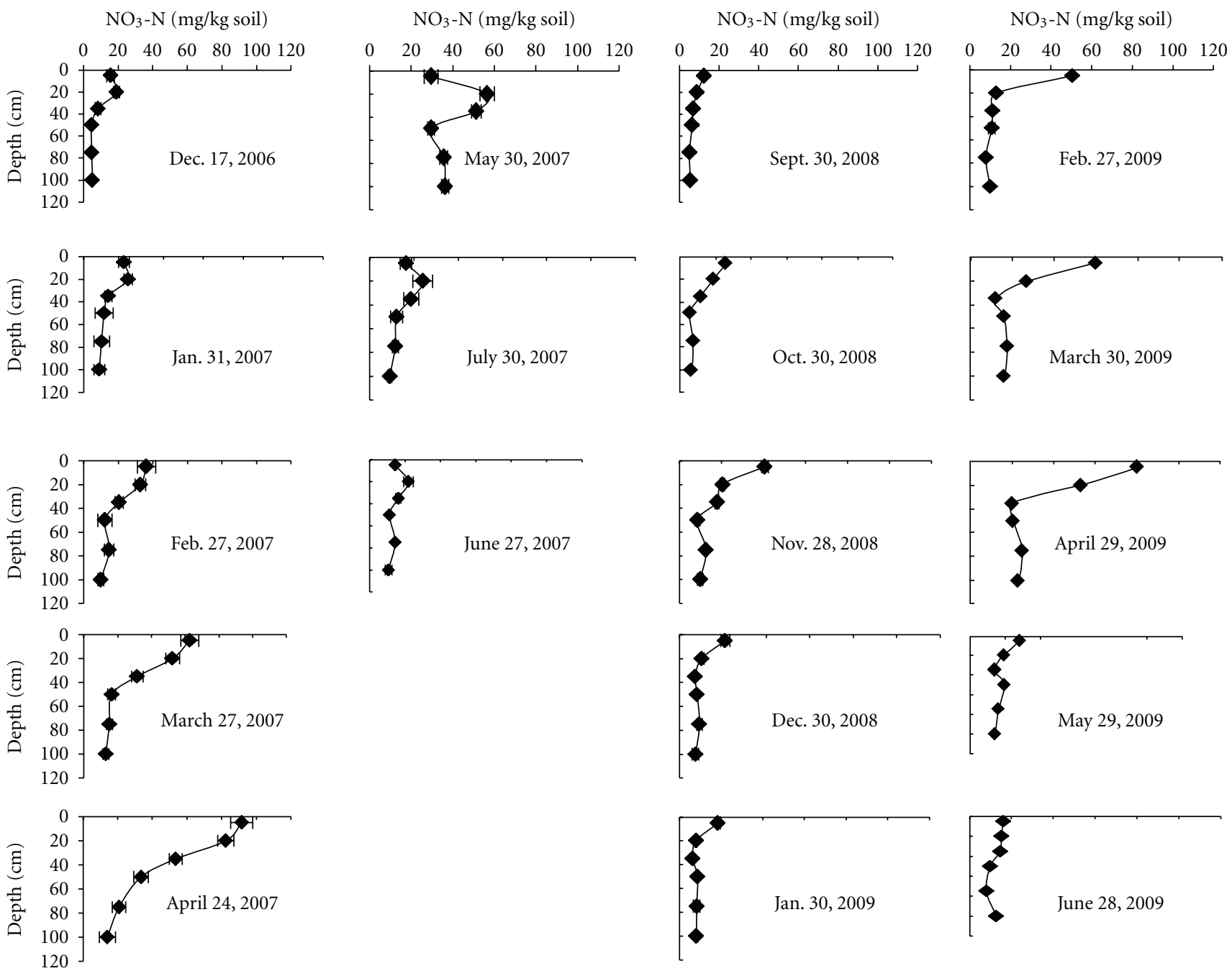

Figure 1: Monthly $\mathrm{NO}_{3}-\mathrm{N}$ concentration $\left(\mathrm{mg} \mathrm{kg}^{-1}\right.$ soil) in the $0-110 \mathrm{~cm}$ soil profile during two onion growing seasons (2006-09) in furrowirrigated onion field in NM. The horizontal bars represent standard errors of the mean. Each data point is the mean of three replicate soil samples.

3.7. Nitrate- $N$ Loading. The Nitrate- $\mathrm{N}$ and chloride ratio was used in (4) to calculate the amount of $\mathrm{NO}_{3}-\mathrm{N}$ percolated below the rooting zone of onion, and an averaged accumulated $\mathrm{NO}_{3}-\mathrm{N}$ loading of $150 \pm 2.2 \mathrm{~kg} \mathrm{ha}^{-1}$ and 145 $\pm 0.5 \mathrm{~kg} \mathrm{ha}^{-1}$ was obtained in growing seasons 1 and 2 , respectively, for soil depths below the rooting zone of furrowirrigated onion. The $\mathrm{NO}_{3}-\mathrm{N}$ loading was significantly higher $(P<0.01)$ during growing season 1 than growing season 2 because all fertilizer applications were made during February, March, and April in the growing season 1 whereas fertilizer applications were spread over four months (October, February, March, and April) during growing season 2. The $\mathrm{N}$ front leached to a maximum depth of $149 \mathrm{~cm}$ in growing season 1 indicating that the $\mathrm{NO}_{3}-\mathrm{N}$ below $149 \mathrm{~cm}$ depth was from the previous year. As same crop rotation was practiced in this field for many years and also the inputs such as water and $\mathrm{N}$ fertilizer were nearly the same during each growing season, therefore, this method can be used to estimate $\mathrm{N}$ leaching below root zone during these past years.
The average accumulated $\mathrm{NO}_{3}-\mathrm{N}$ loading estimated below the rooting zone of onion was $79 \pm 6.9 \mathrm{~kg} \mathrm{ha}^{-1}$ and 76 $\pm 0.3 \mathrm{~kg} \mathrm{ha}^{-1}$ during growing seasons 1 and 2, respectively, for the drip-irrigated field. Similar to the furrow-irrigation system, the $\mathrm{NO}_{3}-\mathrm{N}$ concentration in the soil water below $86 \mathrm{~cm}$ depth represented the $\mathrm{NO}_{3}-\mathrm{N}$ concentration from the previous year onion crop in the drip irrigation system. Almost similar amount of fertilizer was applied during both the growing seasons in furrow- and drip-irrigated fields but still $47 \%$ less $\mathrm{NO}_{3}-\mathrm{N}$ loading during growing season 1 and $47.5 \%$ less during growing season 2 was recorded in dripthan in the furrow-irrigated field.

3.8. Nitrogen and Water Balance. The water balance presented an unaccounted amount of $8 \pm 1.2 \mathrm{~cm}$ and $8 \pm 0.6 \mathrm{~cm}$ of water during growing seasons 1 and 2, respectively, for of the total water received in the furrow-irrigated field (Table 6). Similarly, water balance in drip-irrigated field also showed 

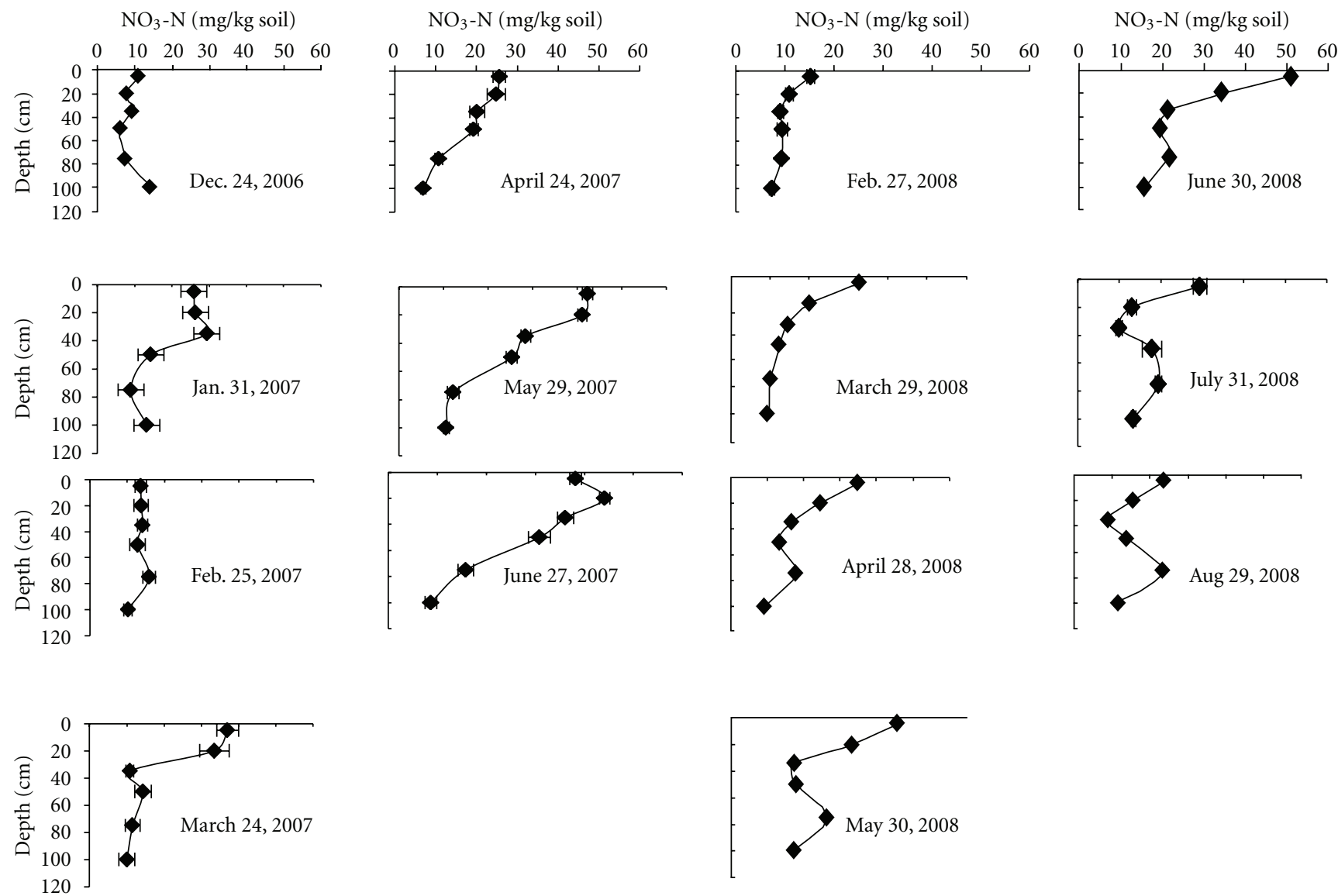

Figure 2: Monthly $\mathrm{NO}_{3}-\mathrm{N}$ concentration $\left(\mathrm{mg} \mathrm{kg}^{-1}\right.$ soil) in the $0-110 \mathrm{~cm}$ soil profile during two onion growing seasons (2006-08) in dripirrigated onion field in NM. The horizontal bars represent standard errors of the mean. Each data point is the mean of three replicate soil samples.

an unaccounted amount of $5 \pm 1.72 \mathrm{~cm}$ and $0.5 \pm 0.5 \mathrm{~cm}$ during growing seasons 1 and 2, respectively (Table 7). Water application efficiency was $72 \pm 0.35 \%$ and $70 \pm 0.43 \%$ during growing seasons 1 and 2, respectively, for the furrowirrigated field and $77 \pm 0.37 \%$ during growing season 1 and $82 \pm 0.40 \%$ during growing season 2 for the drip-irrigated field. Water application efficiency was significantly higher $(P<0.05)$ in drip-irrigated field than in furrow-irrigated field during both the growing seasons. A higher amount of water and less frequent irrigations were applied to the furrow-irrigated field than the drip-irrigated field in this study. The chloride balance error in the drip-irrigated field could also be due to soil sampling errors, as the water flow is not one dimensional in drip irrigation system.

In the furrow-irrigated field, total $\mathrm{N}$ output $-\mathrm{N}$ loss plus $\mathrm{N}$ uptake plus storage of $\mathrm{NO}_{3}-\mathrm{N}$ in soil profile-from the soil profile during the entire growing season 1 was $294 \pm$ $1.8 \mathrm{~kg} \mathrm{Nha}^{-1}$ and was $297 \pm 3.1 \mathrm{~kg} \mathrm{Nha}^{-1}$ during growing season 2 against the total input of $295 \mathrm{~kg} \mathrm{Nha}^{-1}$ during both the growing seasons, in the form of URAN fertilizer (Table 6).

Nitrogen application efficiency was $35 \pm 0.21 \%$ and $36 \pm$ $0.1 \%$ during growing seasons 1 and 2 , respectively, whereas $\mathrm{N}$ use efficiency was $26.7 \pm 0.06 \%$ during growing season 1 and
$28 \pm 0.05 \%$ during growing seasons 2 . Nitrogen application and use efficiencies were significantly higher $(P<0.05)$ in growing season 2 than in growing season 1 , respectively. If the antecedent $\mathrm{N}$ level in the soil is sufficient for plant growth, $\mathrm{N}$ use efficiency can be increased by reducing the amount of fertilizer applied. $\mathrm{N}$ use efficiencies obtained in this study were greater (by about 15\%) than those reported by [9] and less $(30 \%)$ than those reported by [10] for onion under a furrow-irrigation system.

In the drip-irrigated field, total $\mathrm{N}$ output during the entire growing season 1 was $281 \pm 3.8 \mathrm{~kg} \mathrm{~N} \mathrm{ha}^{-1}$ and $278 \pm$ $2.1 \mathrm{~kg} \mathrm{~N} \mathrm{ha}^{-1}$ during growing season 2 against the total input of $292 \mathrm{~kg} \mathrm{~N} \mathrm{ha}^{-1}$ and $286 \mathrm{~kg} \mathrm{~N} \mathrm{ha}^{-1}$ during growing seasons 1 and 2, respectively, in the form of URAN fertilizer (Table 7). The total $\mathrm{N}$ output can be smaller due to mineralization of sudan grass that might have taken place in the rooting zone during the growing seasons. $\mathrm{N}$ use efficiency was $31 \pm 0.25 \%$ and $32 \pm 0.21 \%$ during growing seasons 1 and 2 , respectively, whereas NAE was $38 \pm 0.20 \%$ during growing season 1 and $39 \pm 0.18 \%$ during growing season 2 in the drip-irrigated field. The unaccounted $\mathrm{N}$ in the $\mathrm{NO}_{3}-\mathrm{N}$ balances might be due to denitrification taking place in the rooting zone or to the unaccounted $\mathrm{N}$ present in onion foliage at the time of harvesting. Nitrogen application and use efficiencies were 

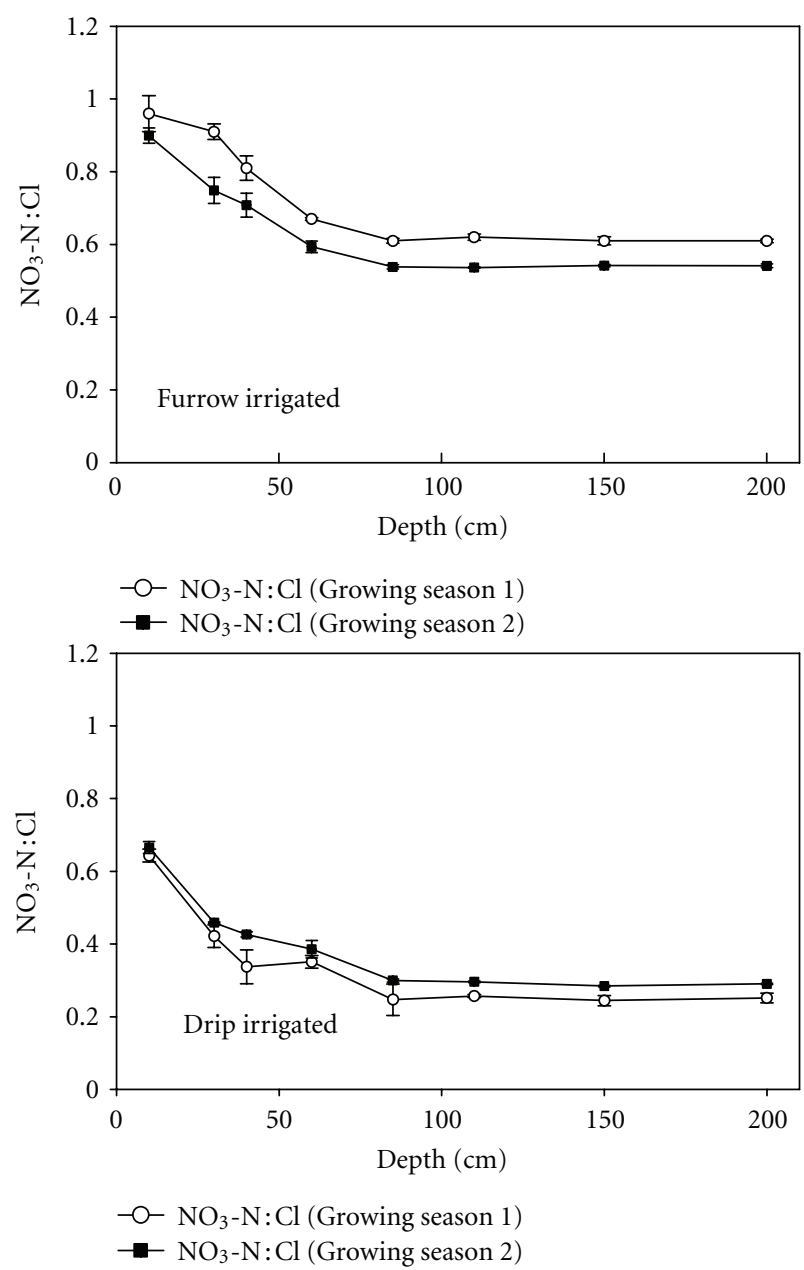

Figure 3: $\mathrm{NO}_{3}-\mathrm{N} / \mathrm{Cl}$ ratio at a $0-200 \mathrm{~cm}$ soil depth during two onion growing seasons in furrow- (2006-09) and drip-irrigated (2006-08) onion fields in NM. The vertical bars represent standard errors of the mean. Each data point is the mean of three replicate samples.

significantly higher $(P<0.05)$ in the drip-irrigated field than in the furrow-irrigated field during both the growing seasons.

In this study, $\mathrm{N}$ mineralization, denitrification $\mathrm{N}$ loss and $\mathrm{N}$ content of the onion foliage at harvesting were not determined and hence were not included in the $\mathrm{N}$ balance calculations for both fields. A search in the literature revealed that a total denitrification $\mathrm{N}$ loss of $51.2 \mathrm{~kg} \mathrm{~N}$ was reported for the agricultural fields, with a total fertilizer application of $335 \mathrm{~kg} \mathrm{~N} \mathrm{ha}^{-1}$ [38], whereas it varied from 27 to $49 \mathrm{~kg} \mathrm{Nha}^{-1}$ with the total fertilizer application ranging from 225 to $335 \mathrm{~kg} \mathrm{Nha}^{-1}$ [39]. Literature searches did not yield any information on the $\mathrm{N}$ mineralization of sudan grass for southern New Mexico. Plow-down alfalfa was reported to contribute $35-125 \mathrm{~kg} \mathrm{Nha}^{-1} \mathrm{yr}^{-1}$ in the soil through mineralization [40,41]. Sullivan [35] found 10 to $20 \%$ of the total onion $\mathrm{N}$ uptake to be present in onion foliage at the time of harvesting. Looking at the above numbers, it seemed that all the three factors of $\mathrm{N}-$ mineralized $\mathrm{N}$, denitrified $\mathrm{N}$, and $\mathrm{N}$ in the onion foliage-together could account for the $\mathrm{N}$ mass balance error obtained in the current study.

3.9. Leaching. Using (3), an LF of $0.20 \pm 0.006$ or IE ( $1-\mathrm{LF})$ of $80 \pm 0.60 \%$ during growing season 1 and an LF of $0.22 \pm$ 0.004 or IE $(1-\mathrm{LF})$ of $78 \pm 0.40 \%$ during growing season 2 were obtained for the furrow-irrigated field (Table 6). The LF during growing season 2 was significantly higher $(P<$ 0.05 ) than the LF during growing season 1 . An LF of 0.28 during growing season 1 and 0.30 during growing season 2 was estimated using water balance method. This indicated a low LF or high IE values using chloride tracer method as compared with the values obtained with water balance method.

Similarly, an LF of $0.17 \pm 0.02(\mathrm{IE}=83 \pm 2.0 \%)$ during growing season 1 and an LF of $0.17 \pm 0.007(\mathrm{IE}=83 \pm 0.7 \%)$ during growing season 2 were obtained for the drip-irrigated field using (3) (Table 7), whereas the LF obtained using the water balance method was 0.23 (or $\mathrm{IE}=0.77 \%$ ) during growing season 1 and 0.18 (or $\mathrm{IE}=0.82 \%$ ) during growing season 2. Similar to the furrow-irrigated field, the chloride tracer technique underestimated the LF and overestimated the IE for the drip-irrigated field. During both the growing seasons, LF was significantly higher $(P<0.05)$ for the furrow- than drip-irrigated field.

Average IEs ranging from 45 to $77 \%$ were reported for onion under drip irrigation systems, in which five different irrigation applications of $40,60,80,100$, and $120 \%$ of the nonstressed $E_{t}$ were applied to onion crop at the FGRC in Las Cruces, NM [42]. In the present study, by contrast, irrigation applications of $79 \%$ and $83 \%$ during growing seasons 1 and 2 , respectively, of the nonstressed $E_{t}$ were applied to furrowirrigated field whereas irrigation applications of $81 \%$ during growing season 1 and $72 \%$ during growing season 2 of the nonstressed $E_{t}$ were applied to drip-irrigated field. The high IE obtained in this study under both irrigation systems is due to the deficit irrigation practiced in the study area to maximize yield from a unit of water rather than from a unit of land, since water is a limited resource in this region.

3.10. Best Management Approach. Plant N uptake was measured as $104 \pm 0.21 \mathrm{~kg} \mathrm{ha}^{-1}$ and $106 \pm 0.1 \mathrm{~kg} \mathrm{ha}^{-1}$ during growing seasons 1 and 2, respectively, in furrow- and $112 \pm$ $0.20 \mathrm{~kg} \mathrm{ha}^{-1}$ during growing season 1 and $111 \pm 0.27 \mathrm{~kg} \mathrm{ha}^{-1}$ during growing season 2 in drip-irrigated fields. Nitrogen application efficiency can theoretically be as high as water application efficiency; however, traditional best management practices result in NAEs of 50\% [35]. Since NAEs in the present study were $35 \%$ and $36 \%$ in growing seasons 1 and 2 , respectively, for furrow- and $38 \%$ in growing season 1 and 39\% in growing season 2 for drip-irrigated fields, this indicated considerable potential for improvement in nitrogen management in onion crop of NM.

The average soil $\mathrm{NO}_{3}-\mathrm{N}$ was high $\left(84 \mathrm{kgha}^{-1}\right.$ during growing season 1 and $94 \mathrm{kgha}^{-1}$ during growing season 2 in furrow- and $52.2 \mathrm{~kg} \mathrm{ha}^{-1}$ during growing season 1 and $78 \mathrm{~kg} \mathrm{ha}^{-1}$ during growing season 2 in drip-irrigated fields) in the early growing season when there was very low 

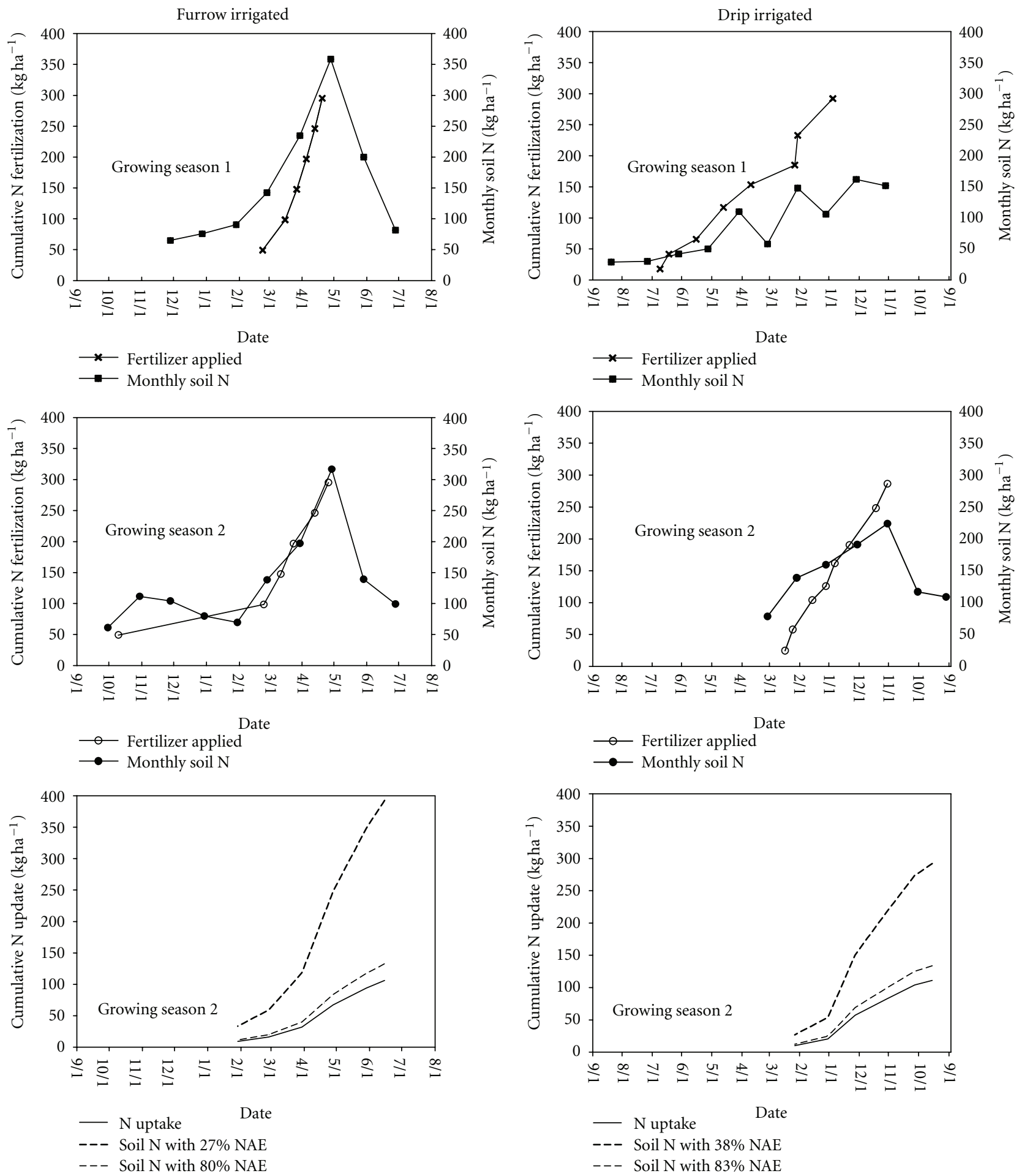

(a)

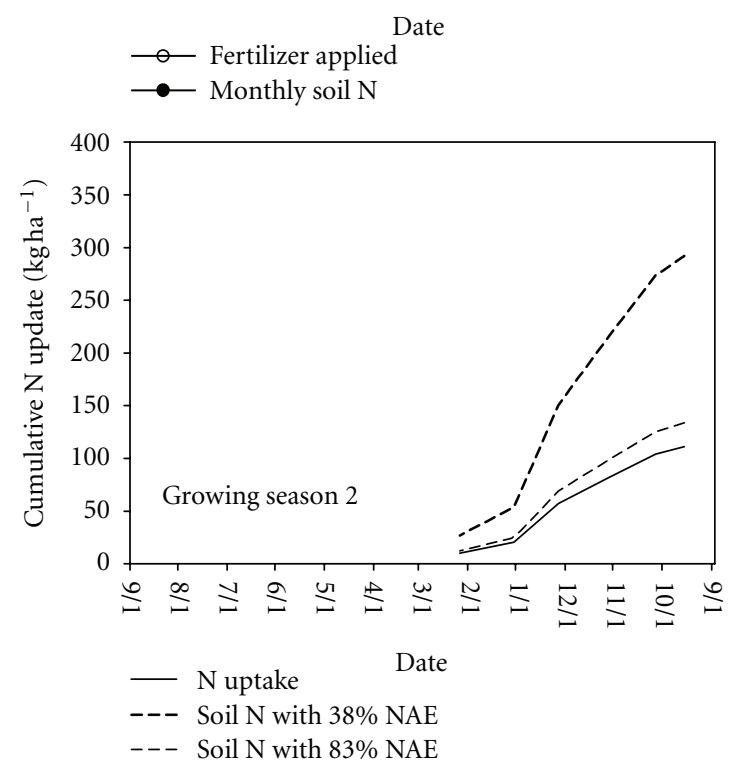

(b)

FIGURE 4: Cumulative $\mathrm{N}$ fertilization $\left(\mathrm{kg} \mathrm{ha}^{-1}\right)$, cumulative $\mathrm{N}$ uptake $\left(\mathrm{kg} \mathrm{ha}^{-1}\right)$ and monthly soil $\mathrm{N}\left(\mathrm{kg} \mathrm{ha}^{-1}\right)$ during two onion growing seasons each in furrow- (2006-09) and drip-irrigated (2006-08) onion fields in NM. NAE is the nitrogen application efficiency.

$\left(<11 \mathrm{~kg} \mathrm{ha}^{-1}\right)$ onion $\mathrm{N}$ uptake (Figure 4). Halvorson et al. [9] reported that onions need a maximum amount of $\mathrm{N}$ during bulbing, when rapid formation of bulb dry matter takes place. Therefore, better $\mathrm{N}$ management would be to start $\mathrm{N}$ application just before bulbing (early March) to provide $\mathrm{N}$ during the period of maximum need by onion plants and possibly reduce $\mathrm{NO}_{3}-\mathrm{N}$ leaching, hence improving NAE in both fields. 
In the furrow-irrigated field, soil $\mathrm{NO}_{3}-\mathrm{N}$ was $235 \mathrm{~kg} \mathrm{ha}^{-1}$ and $197 \mathrm{~kg} \mathrm{ha}^{-1}$ during March and it increased to $359 \mathrm{~kg}$ $\mathrm{ha}^{-1}$ and $317 \mathrm{~kg} \mathrm{ha}^{-1}$ during April in growing seasons 1 and 2 , respectively, as fertilizer applications were made during March and April (Figure 4). Most of the excess soil $\mathrm{NO}_{3}-\mathrm{N}$ probably leached with irrigation, as the soil $\mathrm{NO}_{3}-\mathrm{N}$ during May decreased compared to soil $\mathrm{NO}_{3}-\mathrm{N}$ during April. As the total onion $\mathrm{N}$ uptake was $104 \mathrm{~kg} \mathrm{ha}^{-1}$ and $106 \mathrm{~kg} \mathrm{ha}^{-1}$ during the entire growing seasons 1 and 2, respectively, therefore, a soil $\mathrm{N}$ of $150 \mathrm{~kg} \mathrm{ha}^{-1}$ is sufficient throughout the growing season starting from March. This soil $\mathrm{NO}_{3}-\mathrm{N}$ concentration can be maintained by reducing the amount of $\mathrm{N}$ to half during March and April, with a total $\mathrm{N}$ fertilizer application of $196 \mathrm{~kg} \mathrm{ha}^{-1}$ through the entire growing season.

A single application of $\mathrm{N}$ before March might be sufficient for onion plants in drip-irrigated field, and $\mathrm{N}$ applications during December, January, and February during growing season 1 could be skipped for better $\mathrm{N}$ management (Figure 4). Most of the $\mathrm{N}$ fertilizer applied before March probably leached with irrigation water, as onion roots were only 10 to $15 \mathrm{~cm}$ deep until March. Curtailing excess fertilizer applications before March would reduce the total fertilizer application from 292 to $190 \mathrm{~kg} \mathrm{ha}^{-1}$ during growing season 1. Similarly, by reducing the current $\mathrm{N}$ fertilizer applied during March, April, and June during the growing season 2 to half would reduce the total fertilizer application from 286 to $175 \mathrm{~kg} \mathrm{ha}^{-1}$. These results also showed that regular soil sampling is important to monitoring soil $\mathrm{NO}_{3}-\mathrm{N}$ throughout the growing season.

The limitation of this study, in the drip-irrigated field, could be the difference in the planting dates of onion. However, this is a common practice in this area where farmers grow onion during fall followed by spring onion. Despite of this limitation, this study provided a detailed sketch of $\mathrm{NO}_{3}-\mathrm{N}$ leaching and discussed the improvements that can be made to reduce the $\mathrm{NO}_{3}-\mathrm{N}$ leaching in the farmers' fields of New Mexico.

\section{Conclusions}

Greater $\mathrm{N}$ concentrations were found in the onion crop rooting zone than below the rooting zone depth in both the furrow- and drip-irrigated onion in NM. The average $\mathrm{NO}_{3}-\mathrm{N}$ loading flux below the rooting zone was $150 \pm$ $2.2 \mathrm{~kg} \mathrm{ha}^{-1}$ and $145 \pm 0.5 \mathrm{~kg} \mathrm{ha}^{-1}$ during growing seasons 1 and 2 , respectively, at an average volumetric water content of $0.19 \mathrm{~cm}^{3} \mathrm{~cm}^{-3}$ in furrow-irrigated field. Similarly, average $\mathrm{NO}_{3}-\mathrm{N}$ loading flux below the rooting zone of dripirrigated field was $79 \pm 6.9 \mathrm{~kg} \mathrm{ha}^{-1}$ and $76 \pm 0.3 \mathrm{~kg} \mathrm{ha}^{-1}$ during growing seasons 1 and 2, respectively, at an average volumetric water content of $0.32 \mathrm{~cm}^{3} \mathrm{~cm}^{-3}$. The ratio of $\mathrm{NO}_{3}-\mathrm{N}$ and $\mathrm{Cl}$ decreased with increasing soil depth and was similar below the onion rooting zone $(50-200 \mathrm{~cm})$ in the furrow- and drip-irrigated fields. A leaching fraction of 0.20 \pm 0.006 and $0.22 \pm 0.004$ during growing seasons 1 and 2 , respectively, was obtained for the furrow-irrigated field and $0.17 \pm 0.02$ during growing season 1 and $0.17 \pm 0.007$ during growing season 2 for the drip-irrigated field using the chloride tracer technique. Therefore, irrigation efficiencies $(1-\mathrm{LF})$ under both systems were high: $80 \pm 0.6 \%$ and 78 $\pm 0.004 \%$ during growing seasons 1 and 2 , respectively, for the furrow-irrigated field and $83 \pm 2.0 \%$ during growing season 1 and $83 \pm 0.7 \%$ during growing season 2 for the dripirrigated field. The chloride tracer technique underestimated the leaching fractions and, therefore, overestimated the IEs for both irrigation systems compared to the water-balance method. Nitrogen application and use efficiencies were low in both fields because of high levels of available $\mathrm{N}$ in the root zone due to application of excess $\mathrm{N}$ fertilizer compared with the total amount of $\mathrm{N}$ taken up by the onion plants. Reducing $\mathrm{N}$ application rates by half and delaying $\mathrm{N}$ applications until onion bulbing (early March) starts may improve $\mathrm{N}$ application and use efficiencies and potentially reduce the $\mathrm{N}$ loading in deeper soil layers. More frequent and smaller amounts of water and fertilizer applications can increase retention and reduce the leaching depth of water and fertilizer.

\section{Acknowledgment}

The authors thank the Agricultural Experimental Station of New Mexico State University for funding the project.

\section{References}

[1] F. E. Allison, "The fate of nitrogen applied to soils," Advances in Agronomy, vol. 18, pp. 219-258, 1966.

[2] G. A. Peterson and J. F. Power, "Soil, crop, and water management," in Managing nitrogen for groundwater quality and farm profitability, R. F. Follett, Ed., pp. 189-198, Soil Science Society of America, Madison, Wis, USA, 1991.

[3] M. S. Al-Jamal, T. W. Sammis, and T. Jones, "Nitrogen and chloride concentration in deep soil cores related to fertilization," Agricultural Water Management, vol. 34, no. 1, pp. 1-16, 1997.

[4] P. Cepuder and M. K. Shukla, "Groundwater nitrate in Austria: a case study inTullnerfeld," Nutrient Cycling in Agroecosystems, vol. 64, no. 3, pp. 301-315, 2002.

[5] "Diagnosis and Improvement of saline and alkali soils," in Handbook No. 60, L. A. Richards, Ed., United States Department of Agriculture, Washington, DC, USA, 1954.

[6] W. Stites and G. J. Kraft, "Nitrate and chloride loading to groundwater from an irrigated north-central U.S. sand-plain vegetable field," Journal of Environmental Quality, vol. 30, no. 4, pp. 1176-1184, 2001.

[7] L. J. Lund, "Variations in nitrate and chloride concentrations below selected agricultural fields," Soil Science Society of America Journal, vol. 46, no. 5, pp. 1062-1066, 1982.

[8] L. Bergstrom and R. Johansson, "Leaching of nitrate from monolith lysimeters of different types of agricultural soils," Journal of Environmental Quality, vol. 20, no. 4, pp. 801-807, 1991.

[9] A. D. Halvorson, R. F. Follett, M. E. Bartolo, and F. C. Schweissing, "Nitrogen fertilizer use efficiency of furrowirrigated onion and corn," Agronomy Journal, vol. 94, no. 3, pp. 442-449, 2002.

[10] T. W. Sammis, "Nutrient management of onions: a New Mexico perspective," in Proceedings of the Western Nutrient 
Management Conference, vol. 2, pp. 49-53, Salt Lake City, Utah, USA, March 1997.

[11] D. Romic, M. Romic, J. Borosic, and M. Poljak, "Mulching decreases nitrate leaching in bell pepper (Capsicum annuum L.) cultivation," Agricultural Water Management, vol. 60, no. 2, pp. 87-97, 2003.

[12] D. A. Bucks, L. J. Drie, and O. F. French, "Quality and frequency of trickle and furrow irrigation for efficient cabbage production," Agronomy Journal, vol. 66, no. 1, pp. 53-56, 1974.

[13] C. D. Gustafson, "Drip irrigation-worldwide 1975, present status and outlook for drip irrigation," Survey Report of University of California, University of California, San Diego, Calif, USA, 1975.

[14] A. D. Halvorson, M. E. Bartolo, C. A. Reule, and A. Berrada, "Nitrogen effects on onion yield under drip and furrow irrigation," Agronomy Journal, vol. 100, no. 4, pp. 1062-1069, 2008.

[15] P. F. Pratt, L. J. Lund, and J. M. Rible, "An approach to measuring leaching of nitrate from freely drained irrigated fields," in Nitrogen Behavior in Field Soil, D. R. Nielsen and J. G. MacDonald, Eds., vol. 1, pp. 223-265, Academic Press, New York, NY, USA, 1978.

[16] Z. Samani, T. Sammis, R. Skaggs, N. Alkhatiri, and J. Deras, "Measuring on-farm irrigation efficiency with chloride tracing under deficit irrigation," Journal of Irrigation and Drainage Engineering, vol. 131, no. 6, pp. 555-559, 2005.

[17] D. P. Genereux, S. J. Wood, and C. M. Pringle, "Chemical tracing of interbasin groundwater transfer in the lowlandrainforest of Costa Rica," Journal of Hydrology, vol. 258, no. 1-4, pp. 163-178, 2002.

[18] M. K. Shukla and P. Cepuder, "Anion exclusion during transport of chloride through soil columns," Transactions of the American Society of Agricultural Engineers, vol. 43, no. 6, pp. 1425-1430, 2000.

[19] M. K. Shukla, T. R. Ellsworth, R. J. Hudson, and D. R. Nielsen, "Effect of water flux on solute velocity and dispersion," Soil Science Society of America Journal, vol. 67, no. 2, pp. 449-457, 2003.

[20] B. A. Stewart, "Critique of an approach to measuring leaching of nitrate from freely drained irrigated fields," in Nitrogen Behavior in Field Soil, D. R. Nielson and J. G. MacDonald, Eds., vol. 1, pp. 267-273, Academic Press, New York, NY, USA, 1978.

[21] H. E. Bulloch and R. E. Neher, Soil Survey of Dona Ana County Area New Mexico, United States Department of Agriculture, Soil Conservation Service, 1980.

[22] L. H. Gile, J. W. Hawley, and R. B. Grossman, Soils and Geomorphology in the Basin and Range Area of Southern New Mexico-Guidebook to the Desert Project, New Mexico Bureau of Mines and Mineral Resources, New Mexico, NM, USA, 1981.

[23] V. E. Hansen, O. W. Israelsen, and G. E. Stringgham, Irrigation Principles and Practices, John Wiley and Sons, New York, NY, USA, 1979.

[24] G. R. Blake and K. H. Hartge, "Bulk density," in Methods of Soil Analysis. Part 1, A. Klute, Ed., Agronomy Monograph, 9, pp. 363-373, American Society of Agronomy, Soil Science Society of America, Madision, Wis, USA, 2nd edition, 1986.

[25] A. Klute and C. Dirksen, "Hydraulic conductivity and diffusivity: laboratory methods," in Methods of Soil Analysis. Part 1, A. Klute, Ed., Agronomy Monograph, 9, pp. 387734, American Society of Agronomy, Soil Science Society of America, Madision, Wis, USA, 2nd edition, 1986.
[26] W. H. Gardner, "Water content," in Methods of Soil Analysis. Part 1, A. Klute, Ed., Agronomy Monograph, 9, pp. 493544, American Society of Agronomy, Soil Science Society of America, Madision, Wis, USA, 2nd edition, 1986.

[27] G. W. Gee and J. W. Bauder, "Particle size analysis," in Methods of Soil Analysis. Part 1, A. Klute, Ed., Agronomy Monograph, 9, pp. 337-382, American Society of Agronomy, Soil Science Society of America, Madision, Wis, USA, 2nd edition, 1986.

[28] D. G. Maynard and Y. P. Kalra, "Nitrate and exchangeable ammonium nitrogen," in Soil Sampling and Methods of Analysis, M. R. Carter, Ed., pp. 25-38, Canadian Society of Soil Science, Lewis Publishers, 1993.

[29] M. S. Al-Jamal, T. W. Sammis, S. Ball, and D. Smeal, "Yieldbased, irrigated onion crop coefficients," Applied Engineering in Agriculture, vol. 15, no. 6, pp. 659-668, 1999.

[30] T. W. Sammis, C. L. Mapel, D. G. Lugg, R. R. Lansford, and J. T. McGuckin, "Evapotranspiration crop coefficients predicted using growing-degree-days," Transactions of the American Society of Agricultural Engineers, vol. 28, no. 3, pp. 773-780, 1985.

[31] K. Thorup-Kristensen, "Root growth and nitrogen uptake of carrot, early cabbage, onion and lettuce following a range of green manures," Soil Use and Management, vol. 22, no. 1, pp. 29-38, 2006.

[32] SAS Institute Incorporation, SAS 9.1 for Windows, Version 9.1.3, Cary, NC, USA, 2002-2003.

[33] N. C. Brady and R. R. Weil, Elements of the Nature and Properties of Soils, Person Education, Upper Saddle River, NJ, USA, 2nd edition, 2004.

[34] Soil Improvement Committee and California Fertilizer Association, Western Fertilizer Handbook, The Interstate Printers and Publishers, Danville, Ill, USA, 6th edition, 1980.

[35] D. M. Sullivan, B. D. Brown, and C. C. Shock, Nutrient Management for Onions in the Pacific Northwest, PNW Extension Bulletin, Washigton, DC, USA; Oregon State University, Corvallis, Ore, USA, 2001.

[36] United States Public Health Service, Drinking Water Standards, vol. 956, United States Public Health Service, 1962.

[37] J. Mikołajków, "Laboratory methods of estimating the retardation factor of migrating mineral nitrogen compounds in shallow groundwater," Geological Quarterly, vol. 47, no. 1, pp. 91-96, 2003.

[38] J. C. Ryden, L. J. Lund, J. Letey, and D. D. Focht, "Direct measurement of denitrification loss from soils: II. Development and application of field methods," Soil Science Society of America Journal, vol. 43, pp. 110-118, 1979.

[39] N. Hofstra and A. F. Bouwman, "Denitrification in agricultural soils: summarizing published data and estimating global annual rates," Nutrient Cycling in Agroecosystems, vol. 72, no. 3, pp. 267-278, 2005.

[40] T. W. Bruulsema and B. R. Christie, "Nitrogen contribution to succeeding corn from alfalfa and red clover," Agronomy Journal, vol. 79, pp. 96-100, 1987.

[41] J. L. Gil and W. H. Fick, "Soil nitrogen mineralization in mixtures of eastern gamagrass with alfalfa and red clover," Agronomy Journal, vol. 93, no. 4, pp. 902-910, 2001.

[42] M. S. Al-Jamal, S. Ball, and T. W. Sammis, "Comparison of sprinkler, trickle and furrow irrigation efficiencies for onion production," Agricultural Water Management, vol. 46, no. 3, pp. 253-266, 2001. 

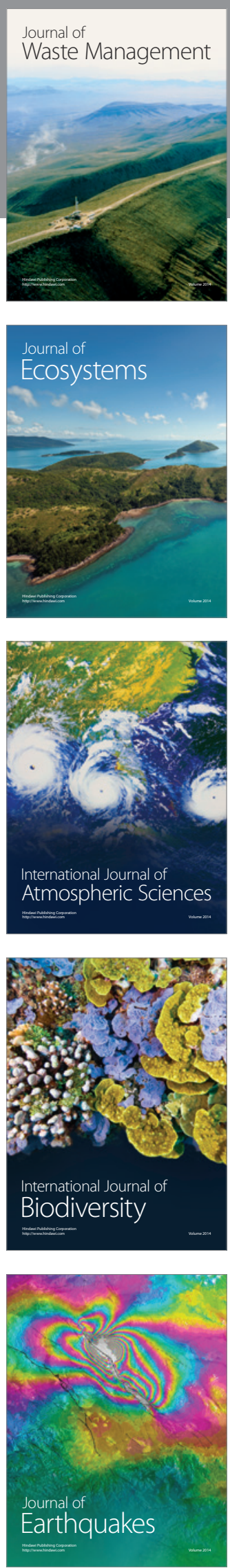
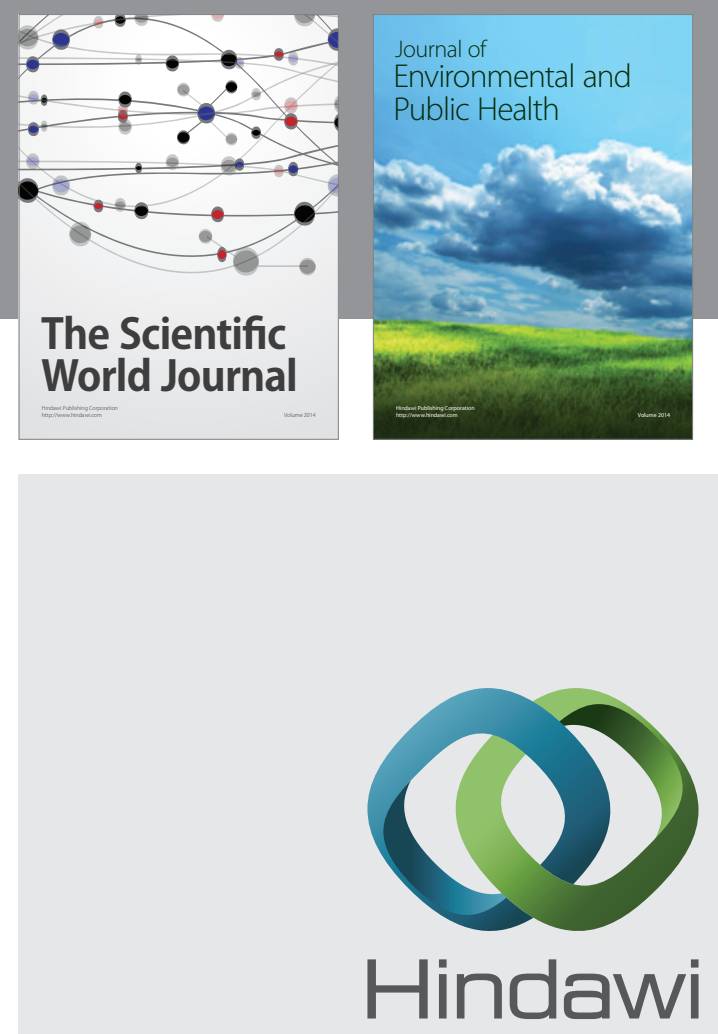

Submit your manuscripts at

http://www.hindawi.com
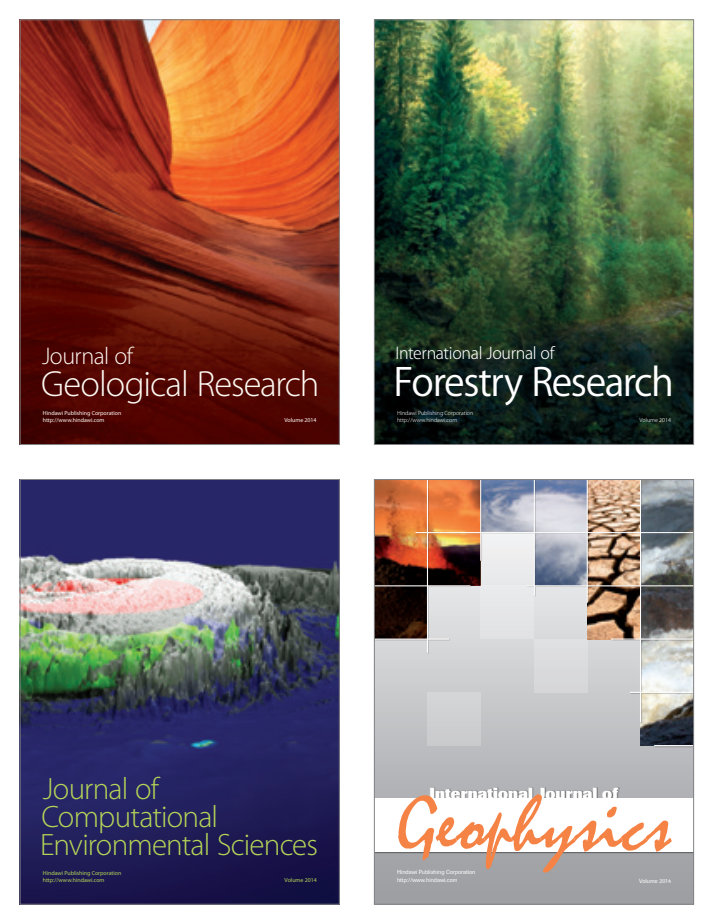
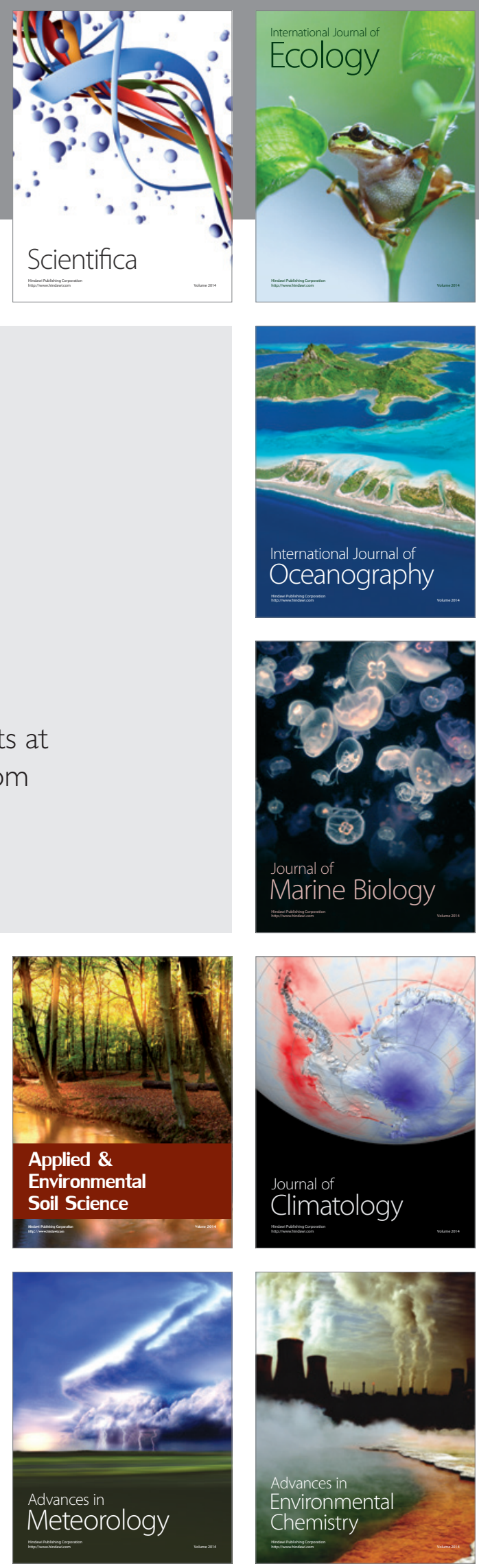